\title{
Versión inédita en castellano de la biografía del P. Francisco Ruiz de Villegas SJ, promotor de la celebración salteña de la Virgen del Milagro
}

\author{
Spanish unedited version of the biography of \\ Fr Francisco Ruiz de Villegas SJ, salteña promoter \\ celebration of the Virgen del Milagro
}

Juan Pedro Kalinowski*

Resumen: El presente trabajo describe en sus líneas principales la participación misional de la Compañía de Jesús en la provincia de Salta (Argentina) y su influencia en la configuración de la identidad e idiosincrasia de dicha provincia. En ese marco contextual, se presenta por primera vez en versión castellana la biografía del P. Francisco Ruiz de Villegas, cuyo original latino de 1793 es autor el Padre de la misma Compañía, el catalán José Manuel Peramás. Se pretende con esto rescatar del olvido y revalorizar su participación como religioso en la conformación y difusión del culto de la Virgen del Milagro, una de las manifestaciones de fe más antiguas y de mayor raigambre del norte argentino.

Palabras claves: Francisco Ruiz de Villegas - biografía - jesuitas - Peramás - Virgen del Milagro.

Abstract: This paper describes in its main lines missionary participation of the Society of Jesus in the province of Salta (Argentina) and its influence in shaping the identity and idiosyncrasies of the province. In this contextual framework it is presented for the first time in the Spanish version the biography of Fr. Francisco Ruiz de Villegas, whose original Latin of 1793 written by the Father of the same Society, Catalan José Manuel Peramás. This is intended to rescue from oblivion and enhance their participation as religious order of San Ignacio in the shaping and dissemination in the cult of the Virgin

\footnotetext{
* Miembro del Centro de Filología Clásica y Moderna de la Universidad Nacional de Villa María. E-mail: juanpkali@gmail.com
} 
of the Miracle, one of the manifestations of faith oldest and most tradition of northern Argentina.

Keywords: Francisco Ruiz de Villegas - biography - Jesuits - Peramás - Virgin of the Miracle.

Recibido: 29 de setiembre de 2016

Evaluado: 18 de noviembre de 2016 


\section{Introducción}

El decreto de expulsión de Carlos III puso fin al casi siglo y medio de labor misional y educadora de la orden de los jesuitas, quienes tuvieron un protagonismo particular en la configuración de la cultura y de las costumbres de la región de la antigua provincia jesuítica del Paraguay, cuyo alcance superó ampliamente la coyuntura de la decisión política de la corona española. Para la difusión de la memoria de esa labor, propia de la identidad de la Orden, algunos de sus miembros tuvieron una especial conciencia de que la literatura, en un sentido amplio del término, era el medio más idóneo y de mayor inserción social, especialmente en el Viejo Continente. En este sentido, la obra biográfica del jesuita catalán José Manuel Peramás es una voz profundamente testimonial y evocadora de nuestros tiempos fundacionales que en esta oportunidad permite conocer la vida y obra de un jesuita salteño poco conocido, Francisco Ruiz de Villegas, quien tuvo un rol fundamental en la creación y difusión de la celebración religiosa del Señor y de la Virgen del Milagro en la ciudad de Salta (Argentina). En este trabajo se presenta la primera versión castellana del original latino del jesuita catalán.

\section{La presencia de los jesuitas en Salta}

Con el fin de consolidar una vía de comunicación entre Perú y el Río de la Plata, a mediados del siglo XVI los españoles iniciaron incursiones de conquista en la región del Tucumán (un territorio que comprendía aproximadamente las actuales provincias de Jujuy, Salta, Tucumán, Catamarca, Santiago del Estero, La Rioja y Córdoba) y de manera paulatina también los misioneros, a la par de los conquistadores, emprendieron la tarea de difundir el Evangelio. En esta etapa se fundaron las ciudades de Londres de la Nueva Inglaterra, Córdoba, Salta, San Miguel de Tucumán y Nuestra Señora de Talavera de Esteco, entre otras, y este crecimiento en el orden civil también se vio reflejado en el plano religioso con la creación de la diócesis del Tucumán, erigida por pedido de Felipe II mediante la bula del Papa Pío V del 14 de mayo de 1570, y fijó su sede en Santiago del Estero.

Pocos años después, en agosto de 1585, fray Francisco de Victoria ${ }^{1}$, obispo del Tucumán desde 1578, hizo traer a su diócesis los primeros misioneros de la Compañía de Jesús que arribaron en dos grupos $^{2}$ : desde Perú llegaron los padres Alonso de Barzana $^{3}$, Francisco de Angulo ${ }^{4}$-como Superior-y

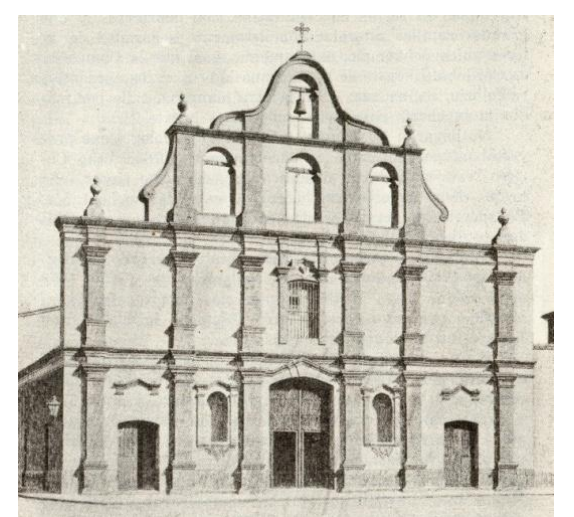

La desparecida iglesia de la Compañía de Jesús de Salta. Dibujo J. Augspurg.

\footnotetext{
${ }^{1}$ Francisco de Victoria (Portugal, 1540 - Madrid, 1592) fue un sacerdote dominico que ejerció como primer Obispo de Tucumán entre 1578 y 1592 gracias al nombramiento del Papa Gregorio XIII y participó junto al gobernador del Tucumán, Hernando de Lerma, en la fundación de la ciudad de Salta. Tiempo después se distanció del gobernador por diferencias de criterio y con él se cruzaron diversas acusaciones, por lo que se estableció en Lima y recién pudo regresar a Santiago del Estero, sede del Obispado, en 1585 .

${ }^{2}$ Lozano, 1755 (I): 5.

3 Alonso de Barzana (Cuenca, 1530 - Cuzco, 1598) luego de su ordenación como sacerdote jesuita, se trasladó a Perú en 1569. En 1577 fue destinado a la misión de Juli, a orillas del Lago Titicaca (Perú), permaneció en la región central de Bolivia y luego el Provincial Juan de Atienza lo envió al Tucumán, desempeñando su trabajo misionero entre los indígenas de la región de los Valles Calchaquíes y poste-
} 
el hermano coadjutor Juan de Villegas ${ }^{5}$, en tanto que desde Brasil en 1587 arribaron el P. Leonardo Armini, como superior, el P. Juan Saloni, el P. Thomas Fields, el P. Esteban de Grao y el P. Manuel de Ortega, que se unieron en Santiago del Estero a los venidos del Perú. La extensión territorial exigía una multiplicidad de actividades apostólicas para las cuales el número de religiosos era claramente escaso. En una Relación anónima del año 1600 puede leerse que "había en la misión del Tucumán y Paraguay, once sacerdotes y dos hermanos ", $\mathrm{y}$ en la misma crónica en relación a la actividad misional del P. Alonso de Barzana, que se destacó particularmente, se señala:

"fue de los primeros que vinieron al Perú de la Compañía y el primero que comenzó a predicar a los indios en su lengua para lo cual le dio nuestro Señor mucho caudal porque en el Perú predicó muchos años en la lengua quichua y aymará, y supo la puquina que es muy dificultosa. En Tucumán aprendió la lengua cacana de Santiago y del valle Calchaquí, que hace mucha diferencia, la tonocoté, la lule, la sanavirona y, al cabo de su vejez, aprendió la lengua guarani"."

Esta facilidad en la adquisición y manejo de lenguas aborígenes favoreció la predicación y, si bien no fueron los primeros evangelizadores de la zona $^{7}$, los jesuitas fueron los más importantes en cuanto a su persistencia e influencia.

La forma de realizar sus misiones se inclinó preferentemente por la gran extensión del territorio a cubrir y por la escasez de religiosos a las misiones comunes y las misiones volantes, ministerio propio de la Compañía que era aplicado tanto en Europa como en América. Las ventajas de las reducciones permanentes de las que ya se tenía experiencia en Santiago del Estero, Asunción y Córdoba, tomaron un nuevo impulso a partir de 1609 cuando el provincial Diego de Torres ${ }^{8}$ consiguió la autorización para que los padres Juan Darío 9 y Horacio Morelli ${ }^{10}$ se ocuparan de los aborígenes del valle de

riormente en el Gran Chaco hasta 1593. Gran conocedor de lenguas indígenas, redactó varios catecismos en quechua y aymara (1583).

${ }^{4}$ Francisco de Angulo (Córdoba (España), 1538 - Sucre, 1611) se ordenó en 1565 y fue destinado en 1577 al Perú y arribó en 1581 en la expedición del procurador Baltasar Piñas. A pedido del obispo Francisco de Vitoria, y autorizado por el provincial Piñas, llegó en 1585 a Santiago del Estero para desempeñarse como superior hasta 1590. En 1598 pasó a Salta y en 1602 a Chuquisaca (hoy Sucre) donde murió. (Baptista, 2001c: 175).

${ }^{5}$ Juan de Villegas (Málaga, 1564 - La Paz, 1601).

${ }^{6}$ Relación anónima del año 1600 citada en Bruno, 1975 (I), 436.

${ }^{7}$ En la expedición de Diego de Rojas de 1543 figuran los padres Francisco Galán y Juan Cedrón; en la de Juan Núñez del Prado, los religiosos Gaspar de Carabajal y Alonso Trueno (dominicos).

${ }^{8}$ Diego de Torres Bollo (Zamora, 1551 - Sucre, 1638). Fue enviado al Perú en 1581 y hasta 1585 se desempeñó como superior de la importante doctrina aymara de Juli. y luego fue el fundador y primer Provincial de la provincia jesuítica del Paraguay (1607 - 1615). Durante su gestión se volvió a abrir la casa de Asunción, se inauguró el colegio de Córdoba y se fundó la residencia de Santa Fe. Al cabo de su provincialato en 1615, pasó a Córdoba de cuyo colegio fue rector poco después.

${ }^{9}$ Juan Darío nació en Altavilla Silentina (Salerno, Italia) en 1562 e ingresó a la Compañía en Roma el 4 de octubre de 1587. Llegó en 1599 al Paraguay y falleció en Santiago del Estero el 8 de junio de 1633 a los 71 años. El detalle de su biografía está desarrollado en la Carta Anua de 1632/1634.

${ }^{10}$ Horacio Morelli nació en Cosenza (Italia) en 1577 e ingresó a la Compañía en Roma el 29 de junio de 1600. Llegó al Paraguay en 1605 e hizo sus últimos votos conocidos en San Miguel de Tucumán el 2 de junio de 1613. Falleció en Quimilpa (Santiago del Estero) el 3 de junio de 1642 a los 65 años. 
Calchaquí e ingresaran a Salta: "asegurándoles no tenían de qué temer entre aquellos lobos porque con su mansedumbre de ovejas, los convertirían en mansos corderos" $"$.

La tarea misional de estos primeros hermanos en territorio salteño fue tal que: "se esforzaron de nuevo a fertilizar aquel Valle con el riego de la Divina palabra de modo que todo el rindiesse colmado fruto espiritual" "12. Y aún más, cuando los pobladores de la ciudad de Salta se anoticiaron de que estos dos misioneros serían destinados a otra parte, en una demostración de la alta estima ganada por ellos, le escribieron una carta al padre provincial Diego de Torres en estos términos:

Reverendísimo Padre Provincial. Hase aumentado en mucho mayor grado el amor, y afición, que los Vecinos, y moradores de esta Ciudad tenemos a la Compañía de Jesús, por la venida de los Padres Juan Darío, y Horacio Morelli, cuya santidad de vida, y religiosas costumbres, por ser tan manifiestas, y notorias, no las referimos aquí. Solo diremos del grande, y conocido fruto, que ha hecho con la conversión de tantas almas, assí del Valle de Calchaquí, como de todos los demás de la jurisdición de esta ciudad, à que con tanto trabajo, y riesgo de la vida se han puesto con tanto amor, zelo, y pecho christiano, con que son amados, y reverenciados de todos en general....

La extensión de la cita es un ejemplo ilustrativo del grado de inserción social y de estima que la Compañía se había ganado entre los pobladores del norte del actual territorio argentino. Junto a dos misiones franciscanas, la tarea de los hombres de San Ignacio se desarrolló en ocho misiones permanentes a lo largo de la gobernación del Tucumán ${ }^{14}$ y en territorio salteño fundaron la reducción de San Carlos en 1642, una en la zona de Cachi y en la región sur, la de Santa María de los Ángeles de Yocavil en un territorio que corresponde en la actualidad a la provincia de Catamarca que, si bien había sido erigida en 1617, se estableció de manera definitiva en 1641.

Por su parte, en Salta capital los jesuitas se radicaron en el año 1612 y frente a la plaza principal edificaron su templo y convento, que fueron demolidos en 1905. También ocuparon algunas casas y estancias que en el año 1588 el gobernador Juan Ramírez de Velasco ${ }^{15}$ les había donado hasta que el 3 de agosto de 1767 se daba cumplimiento a la orden de Carlos III que los expulsaba de América. Gobernaba entonces la región del Tucumán Don Juan Manuel Fernández Campero ${ }^{16}$, quien en cumplimiento de la real

\footnotetext{
${ }^{11}$ Lozano, 1755 (II): 112.

12 Ibíd.: 118.

${ }^{13}$ Ibíd.: 117.

${ }^{14}$ Ibíd.: 111.

15 Juan Ramírez de Velasco (Estollo, 1539 - Santa Fe, 1597) fue el décimo cuarto gobernador del Tucumán (1586 - 1593) que se abocó a la dominación de los indios diaguitas y calchaquíes. Posteriormente fue designado como gobernador del Río de la Plata y del Paraguay (1595 - 1597). Fundó diversas localidades, como La Rioja en 1591, Madrid de la Juntas en 1592 y al año siguiente dio permiso para erigir San Salvador de Jujuy.

${ }^{16}$ Juan Manuel Fernández Campero (Abionzo, 1725 - Madrid, 1791) fue un militar español y funcionario de la corona española en el Perú y en el Tucumán colonial. Llegó al Perú en 1752 e inició su carrera como corregidor de Quispicanchis en el Perú. Luego de ser enviado a Madrid por las autoridades de Lima, regresó al Río de la Plata con la expedición del gobernador de Buenos Aires, Pedro de Cevallos. En virtud de su desempeño en la toma de la Colonia del Sacramento, Cevallos lo recomendó a Carlos III de España para el cargo de gobernador del Tucumán y tomó la posesión del gobierno el 20 de febrero de 1764 hasta el cese de sus funciones en septiembre de 1769. Mientras en Paraguay y Buenos Aires la orden de expulsión fue cumplida por Francisco Bucarelli y Ursúa, en Santiago del Estero, San Miguel de Tucumán y
} 
orden procedió a detenerlos. Aquel 3 de agosto de 1767 estaban en el Colegio de Salta los sacerdotes Andrés Delgado, Andrés de Aztina, Juan del Casti1lo, Pedro Antonio Garay, Domingo Navarro, Domingo Roca, Miguel Tarriba, Luis de Toledo Baltasar Villafañe y los coadjutores Pedro Andreu, Antonio Ferreira, Manuel Rodriguez, Andrés Stella, Juan Wittgen y Juan Cristiano Mayr, que estaba en la estancia de La Caldera ${ }^{17}$. Fueron trasladados incomunicados poco después y desde distintos puntos geográficos, en particular de la zona oeste del gran Chaco, se congregaron en San Esteban de Miraflores como una escala previa a Buenos Aires, de donde partirían a España, sin más pertenencias que el breviario, la ropa puesta y el dinero que pertenecía a cada uno. En el caso particular del P. Francisco Ruiz, los bienes que llevaba fueron detallados por el P. Furlong:

"Entre las cosas del P. Francisco Ruiz, varón egregio por sus virtudes....halláronse quince cuadernillos de papel blanco, un cuadernito manuscrito, un atado de papeles y cartas, un apunte de medio pliego de pa-

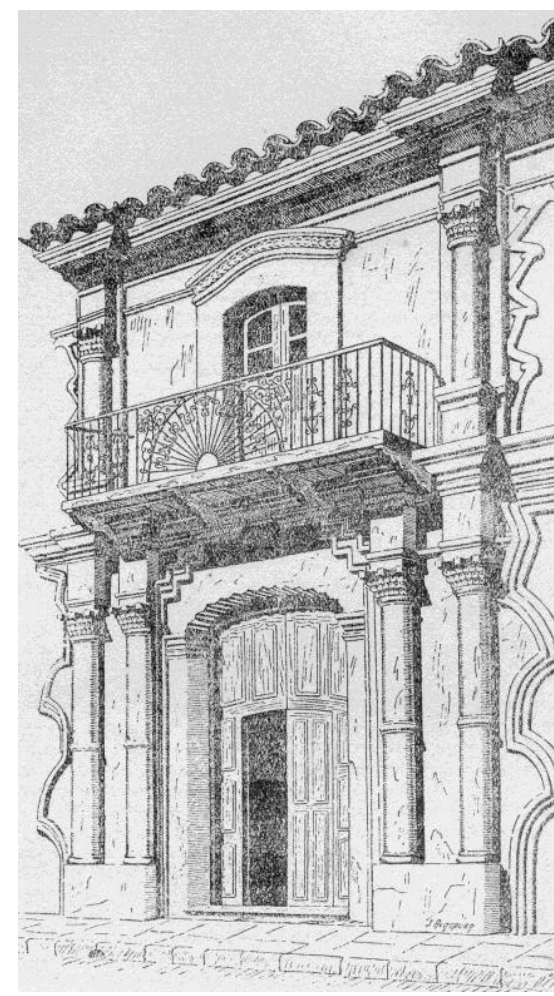

Portal ingreso del Colegio Salta. Dibujo de J. Augspurg.

pel, una pila de prodigiosa agua bendita, un tomito "Compendio de Historia de España, otro de "Verdades eternas", otro de la "Historia de los ejercicios"18.

Así se ponía término a la labor evangelizadora de una orden religiosa que también contó entre sus miembros a individuos nacidos en suelo salteño, como Agustín de Castañares $^{19}$, quien junto con Domingo Bandiera ${ }^{20}$ funda la misión de San Ignacio de

Salta la instrumentó Fernández Campero, quien debió enfrentar también acusaciones ante la Audiencia de Charcas por la dudosa administración de los bienes remanentes de los jesuitas y los fondos de las Reales Cajas de Córdoba. De ambos cargos, el Consejo de Indias en su dictamen final de 1776 lo absuelve, declarando que su actuación había sido conforme a lo dispuesto por la Corona. Tras actuar como corregidor en Perú en 1780, regresa a Madrid para morir en 1791.

${ }^{17}$ Page, 2011c: 117.

${ }^{18}$ Furlong, 1939: 159. La expulsión de los hermanos jesuitas y la distribución en las carretas de muchos de ellos está detallada a partir de la pág. 149 de la obra.

${ }^{19}$ Agustín de Castañares (Salta, 1687 - Salta, 1744) fue alumno del convictorio de Monserrat de Córdoba antes de entrar en la Compañía de Jesús, en donde también cursó filosofía y teología. Fue destinado en 1716 a las misiones de Chiquitos y trabajó en las reducciones de San Rafael y San José. Fracasó en su intento de establecer una reducción entre los zamucos en 1721. Destinado nuevamente a San Rafael en 1736, fue también superior de las misiones de chiquitos hasta 1739. En 1741 lleva a cabo la exploración del Río Pilcomayo desde Asunción del Paraguay. En la región de los indios mataguayos (Salta) encontró una muerte violenta en 1744. El P. Juan de Montenegro, santefecino, trabajó con él y escribió su vida, publicada en Madrid en 1746, a instancias de la marquesa doña Manuela Campero, esposa de don Alejo del Barranco y Martiarena. Fue reeditada por el P. Guillermo Furlong en Buenos Aires en 1964 (Baptista, 2001b: 697).

${ }^{20}$ Domingo Bandiera (Siena, 1693 - Santa Cruz (Bolivia), 1765) llegó a Buenos Aires el 13 de julio de 1717 junto con otros catorce jesuitas italianos en la expedición de los procuradores Bartolomé Jiménez y José de Aguirre. Luego de su ordenación, fue enviado en 1723 a trabajar entre los zamucos en Bolivia en 
los Zamucos (Bolivia) y Francisco Ruiz de Villegas, que se incorpora luego de desempeñarse siete años como sacerdote en la zona rural de Salta y veintitrés como párroco de la misma ciudad de Salta, en un caso poco común de religioso que de la órbita del clero secular recibe el impulso de incorporarse a la Compañía llevado por la inspiración de la Virgen del Milagro ${ }^{21}$.

\section{Ya el castigo estaba // sobre nuestros yerros ${ }^{22}$ o la devoción de la Virgen salteña del Milagro}

La Compañía de Jesús tuvo entre sus principales objetivos la propagación del culto a la Virgen, sobre todo en el siglo XVII, a partir de la aceptación formal de su devoción en $1564^{23}$. Por esa razón, siempre está presente en los sermones, escritos y actividades litúrgicas como "defensora de la fe, madre de todos los predestinados e instrumento para alcanzar el cielo" 24 y en toda ocasión se promovió su culto, como lo hizo el provincial Diego de Torres en el reino de Chile con Nuestra Señora de Loreto para utilidad temporal y espiritual de los fieles ${ }^{25}$ en la primera década del siglo XVII, en tanto que la provincia del Paraguay promovió que en todas las reducciones y colegios se edificaran capillas de Loreto con las mismas dimensiones que la italiana, a la que había visitado.

En la actual provincia de Salta, la adoración a la Virgen está asociada a una donación efectuada por el Obispo de Tucumán fray Francisco de Victoria al pueblo salteño de una imagen de Cristo crucificado cuyo destino era la Iglesia Matriz de la ciudad.

En junio de 1592 la imagen llegó flotando en un cajón al puerto de El Callao, Perú, junto a otro que contenía una imagen de la virgen del Rosario destinada al convento de Santo Domingo, en Córdoba. Nunca se supo qué embarcación las trajo de Espa$\tilde{n} \mathrm{a}^{26}$. Desde Lima las imágenes fueron transportadas a sus destinos y una vez en Salta, la imagen de Cristo fue depositada en la Iglesia Matriz, sin que recibiera ningún tipo de veneración.

Cien años después, el 13 de septiembre de 1692, fuertes movimientos sísmicos hicieron temblar la región del Tucumán y en Salta los fieles se reunieron en la Iglesia

\footnotetext{
un enclave de vital importancia como avanzada en un intento de encontrar una ruta entre las reducciones de Chiquitos con la de los guaraníes del Paraguay (Baptista, 2001a: 335).

${ }^{21}$ También nacieron en Salta los PP. Carlos Aguirre (1722), Juan Hermenegildo Aguirre (1710), Rafael Castañares (1706), Clemente Castellanos (1670), Francisco Castellanos (1664), Francisco Córdoba (1679), Cristóbal Córdoba (1678), Lorenzo Godoy (1691), Juan Cayetano Ibarguren (1715), Eugenio López (1694), Antonio Loza (1722), Pedro Javier Nogal (1737), Francisco Olmos (1678), Buenaventura Porcel de Peralta (1724), Diego Ruiz de Llanos (1670), Cayetano Torres (1724), Francisco Urías (1729), José Joaquín Valdivieso (1737), León de Vergara (1614), Bartolomé de Villagra (1683). Los coadjutores Juan Castellanos (1654), Fernando Córdoba (1669), Eugenio Coronel (1737), Juan de Olmos (1679); y los estudiantes Ignacio de los Reyes (1726) y Domingo Santos (1729) (Storni, 1980: 328-329).

${ }^{22}$ Versos de la $4^{\text {a }}$ estrofa de la poesía a la Virgen del Milagro conocida bajo el nombre "Doce estrellas del cielo de María" de Juan F. J. Fernández y Pedrosa compuesta en 1760 que con el transcurso del tiempo se transformó en el himno a la Virgen del Milagro.

${ }^{23}$ Marin Barriguete, 2003: 1.

${ }^{24}$ Concesión de Gregorio XIII del 13 de octubre de 1584 citado por Marin Barriguette (2003: 1).

${ }^{25}$ Lozano, 1755 (II): 44.

${ }^{26}$ Ibíd.: 39.
}

136 Juan Pedro Kalinowski. Versión inédita en castellano de la biografía ... 130-157. 
Matriz para elevar plegarias en torno a una imagen de la Inmaculada Concepción de María que, desde el retablo del altar mayor en donde se encontraba, se precipitó en el suelo por efectos del terremoto sin que sufriera daños, aunque había perdido el color del rostro.

Al día siguiente, se colocó la imagen de la Virgen en el exterior de la iglesia para su veneración colectiva. Entonces vino a la memoria el Santo Cristo venido desde España que, desde a su llegada en 1592, había permanecido olvidado en el altar de las Ánimas (un lugar secundario unido al cuerpo principal del templo destinado a guardar ornamentos y realizar reuniones).

Según la tradición oral, ese 14 de septiembre de 1692 que amaneció calmo, un sacerdote jesuita, el P. José Carrión ${ }^{27}$, recibe una revelación interior: el Santo Cristo Crucificado, que el pueblo salteño tenía sin devoción y sin culto, había perdonado ese olvido a pedido y súplica de la Inmaculada Concepción, por lo que Salta quedó a salvo de su destrucción. Esta interpretación popular de los acontecimientos y de esos gestos de piedad en torno a la Inmaculada Concepción hizo que ésta fuera llamada por ese motivo la "Virgen del Milagro" y desde entonces, los hermanos de la Compañía de Jesús tuvieron un protagonismo relevante en las celebraciones que se originaron en torno a la Virgen y centrada en Jesucristo, que marcaría la identidad de este pueblo ${ }^{28}$. En efecto, la salvación de la ciudad de Salta fue interpretada como la reaparición del sentido religioso de su pueblo que dejaba atrás los tiempos oscuros de sus yerros y esos nuevos testimonios de fe fueron canalizados por los padres de la Compañía, surgiendo así los cultos del Milagro. Se celebran entre los días 6 y 15 de septiembre de cada año e incluyen una novena ${ }^{29}$, cuyo rezo tiene lugar entre los días 6 y 14 de septiembre, y el solemne Triduo, que se realiza en la Catedral Basílica de Salta los días 13, 14 y 15 de septiembre de cada año, celebrándose en el primero de estos días una misa en homenaje al jesuita José Carrión y en el último una procesión de las Santas Imágenes que recorren las calles principales de la ciudad, acompañadas de ciento de miles de fieles. En este triduo también se obtuvo una indulgencia plenaria, fruto de las gestiones ante el Papa Clemente XIII del P. Francisco Ruiz de Villegas.

Un siglo y medio después, en el año 1845, la imagen del Cristo Crucificado volvió a ser objeto de un acto de reconocimiento al conmemorarse un año del fuerte sismo que había asolado a Salta en octubre de 1844. Ese acto de reconocimiento fue un "pacto de fidelidad" entre el Señor y el pueblo de Salta que se fortaleció en 1892 al conmemorarse el tercer centenario de la llegada de las imágenes a Salta y el segundo de los acon-

\footnotetext{
${ }^{27}$ José Carrión nació en Palencia el 8 de mayo de 1654 e ingresó a la Compañía de Jesús en Castilla el 25 de diciembre de 1671 y el 25 de febrero de 1681 arribó a Buenos Aires. En Mendoza hizo sus últimos votos el 26 de mayo de 1697 y falleció en La Serena, Chile, el 25 de mayo de 1703 (Cartas Anuas de la Provincia Jesuítica del Paraguay 1689/1700, 2015: 190). En la actualidad, por este hecho es recordado en las ceremonias religiosas que se ofician entre el 13 y 15 de septiembre en las celebraciones anuales salteñas de la Virgen del Milagro.

${ }^{28}$ Hay numerosos testimonios de intervenciones milagrosas adjudicadas a la Virgen en los escritos de los padres jesuitas, como es el caso en el que se relata que en el Colegio de Santa Fe sudó la imagen de la Virgen estando presente gran parte de la ciudad. El Vicario de la Catedral y el Rector recogieron el sudor en un paño de algodón al que se le atribuyeron propiedades milagrosas como la cura de enfermedades y de otras dolencias (Page, 2011b: 40).

${ }^{29}$ El presbítero Dr. Francisco Javier Fernández nació en Salta en la segunda década del siglo XVIII y compuso esta Novena cuando tenía alrededor de 25 años que fue observada por el sacerdote jesuita Ignacio Javier de Leiva, considerándola escrita con "notorio celo, piedad y devoción" y el Obispo Miguel de Argandoña en una visita a Salta la aprobó y dio licencia para su divulgación el 5 de diciembre de 1760.
} 
tecimientos de 1692. Siete años más tarde, en 1899, se concretó la coronación pontificia de las imágenes de Cristo y de la Virgen del Milagro con presencia de los obispos diocesanos de la República Argentina. Un nuevo terremoto del 25 de agosto de 1948 motivó la reconfirmación del "pacto de fidelidad" de 1845, el cual pasó a ser renovado cada año para los festejos de septiembre.

En la renovación de este culto a largo del tiempo en sus diversas etapas, el pasado se hace presente de manera constante, fortaleciendo la memoria histórica y el sentido de identidad entre esta devoción del Milagro y la provincia de Salta, configurándose una de las expresiones populares de fe más importantes de la Argentina.

En estas celebraciones religiosas, existe un lugar muy destacado para los miembros de la Compañía de Jesús, pues contribuyeron en la historia y en el espíritu salteño a la configuración y al desarrollo de este culto religioso. Sin embargo, alguno de sus protagonistas no han sido debidamente valorado, quizá por desconocimiento, como es el caso del papel de Francisco Ruiz de Villegas, un religioso que fue decisivo para incentivar y consolidar el sentido devocional y de gratitud hacia la Virgen del Milagro.

\section{La biografía de Francisco de Ruiz de Villegas en la obra peramasiana}

La labor de los religiosos de San Ignacio no solamente se desarrolló en el campo misional y educativo sino también en el ámbito de la producción escrita, considerando a ésta en un sentido amplio que incluía tanto a memoriales, cartas, documentación administrativa, producción científica y literaria. En ésta, un espacio generoso lo ocupaba los escritos asociados al género histórico-biográfico, que tuvo un particular impulso luego de decretarse la expulsión de los padres de territorio español en 1767.

En este cuerpo histórico-biográfico jesuítico, sobresale como uno de los autores más destacados el padre catalán José Manuel Peramás (1732 - 1793) al que Furlong se refirió como:

"un gran humanista, aún más: fue el más grande que produjo el pueblo argentino durante la era colonial. Sus dos series de "Vita et moribus", sus "Laudationes Quinque", su "De administratione guaranitica commentarius", inclusive sus "Cartas Annuas" elogiadas por Cordara son sin excepción obras de genuina elegancia latina y no indignas de los más grandes humanistas europeos" ${ }^{\text {"30. }}$

De la pluma del P. Peramás surge en 1791, editada en su exilio en Faenza, su primera obra de carácter biográfico De vita et moribus sex sacerdotum paraguaycorum $^{31}$, en donde los biografiados son recordados con abundancia de noticias y amenizados con oportunas y valiosas digresiones históricas. Como obra póstuma salió a la luz una segunda obra biográfica, cuidadosamente editada por su hermano Ignacio en 1793, De vita et moribus tredecim virorum paraguaycorum, aunque en realidad es un libro con dos escritos, pues incluye el tratado De administratione guaranitica en su parte ini$\mathrm{cial}^{32}$. Esta serie presenta las mismas características que la primera pero incluye también

\footnotetext{
${ }^{30}$ Furlong, 1984: 121.

${ }^{31}$ Éstos son seis: Manuel Vergara (págs. 1-60), Manuel Querini (págs. 61-102), Juan Andreu (págs. 103169), Juan Escandón (págs. 170-214), Vicente Sans (págs. 215-246) y Segismundo Griera (págs. 247188). Existe una traducción que data de 1946 realizada por Antonio Ballus.

${ }^{32}$ La series vitarum comprende trece biografías: Ignacio Morro (pág. 163-183), Juan Mesner (págs. 184205), Juan Suárez (págs. 205-221), Ignacio Chomé (págs. 221-263), Francisco Ruiz de Villegas (págs.
} 
sacerdotes nacidos en estas tierras, como el cordobés Clemente Baigorrí, el salteño Francisco Ruiz de Villegas o el santiagueño Francisco Urrejola.

En líneas generales, las obras del padre catalán contemplan las normativas retóricas que la tradición greco-latina había consagrado en la disposición de las biografías, es decir, agrupa el relato de las vidas en series que entretejen observaciones del autor, testimonios orales o documentales que más que privilegiar la categoría temporal de los acontecimientos se concentra en la descripción de episodios y las cualidades personales para determinar la imagen de sus personajes. Son previsibles los tópicos biográficos como el nacimiento y familia, la educación, los años juveniles, la función pastoral, las virtudes personales, el dolor del exilio y la muerte con la ilustración de descripciones geográficas, de situaciones que describen el medio social $\mathrm{u}$ opiniones personales del autor que reflejan una técnica compositiva que transforman a sus biografías en una dimensión de lectura de gran valor de un período histórico. Así, la obra biográfica peramasiana toda revela gratitud y reconocimiento hacia los miembros de la Compañía pero también es una indiscutible defensa de la obra apostólica y educativa de la Orden contra las políticas europeas adversas que ya habían dado sus frutos con la expulsión de la Orden de Francia, Portugal y España.

En lo que concierne a la estructura narrativa de la biografía de Francisco Ruiz de Villegas, que ocupa las páginas 263 a 281 de la obra editada post mortem, puede resumirse de la siguiente manera:

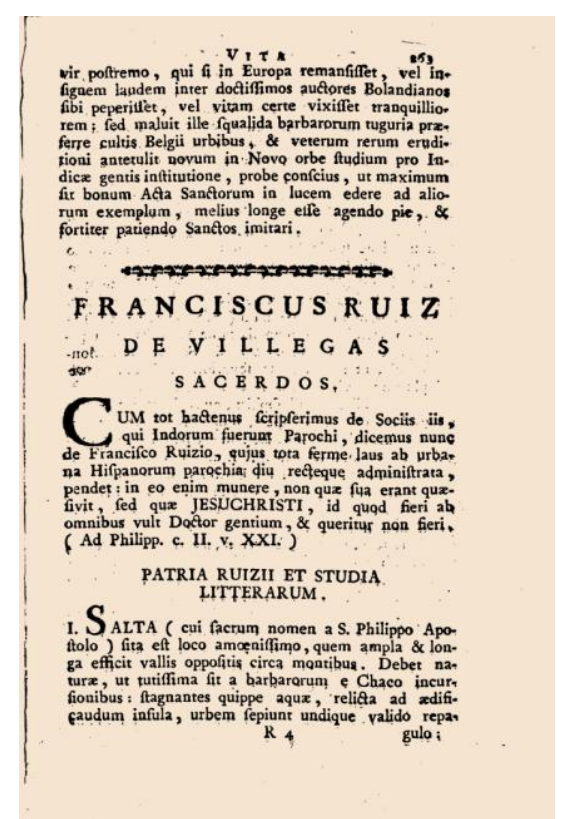

Versión latina de la biografía del P. Francisco Ruiz escrita por el P. Peramás y publicada en 1793.

- I a VII: Nacimiento, educación y obtención de beca para culminar su formación.

- VIII a XII: Se desempeña como párroco rural y de Salta.

- XIII a XIX: Su relación con los pobres.

- XX a XXII: La compasión de Ruiz.

- XXIII a XXVII: La piedad de Ruiz. Su veneración a la Virgen del Milagro.

- XXVIII a XXXV: Se encamina hacia la Compañía de Jesús. El desconcierto del pueblo salteño.

263-281), Juan Angel Amílaga y Antonio del Castillo (págs. 281-304), Esteban Pallozi (págs. 304-323), Clemente Baigorrí (págs. 329-363), Francisco Urrejola y Joaquín Irribarren (págs. 364-375), Cosme Agulló (págs. 376-404) y Martín Schmid (págs. 405-460). Hasta la fecha, sólo existen traducciones de algunos de ellos, como la de Clemente Baigorrí hecha por Ítalo Miguel Viotto "Vida del estudiante Clemente Baigorrí”, en Jesuitas: 400 años en Córdoba, Tomo 3, Córdoba, 1999. Hay versiones al italiano de las correspondientes a Juan Escandón, Clemente Baigorrí y Juan Andreu publicadas por el Padre Boero en 1870 (cfr. Guillermo Furlong, Cinco oraciones laudatorias en honor del Dr. D. Ignacio Duarte y Quirós, pág. 36 y ss.). De la primera parte existe una traducción y notas de 1946 a cargo de Juan Cortés del Pino La República de Platón y los guaraníes, Buenos Aires, Ed. Emecé, y otra más reciente del año 2004 a cargo de Francisco Fernández Pertiñez y Bartolomé Meliá editada por el Centro de Estudios Paraguayos “Antonio Guash” de Asunción del Paraguay. 
- XXXVI a XL: Es desterrado a Europa.

- XLI a XLIV: Su muerte.

Los cuarenta y cuatro parágrafos que componen el relato biográfico poseen un marcado tono encomiástico que se concentra en un religioso que sólo pasó los últimos diez años como jesuita, en uno de los pocos casos que se registran de miembros del clero secular que ingresan a la Orden de San Ignacio. A la luz de la información que surge de los parágrafos VIII a XXVII, su función como sacerdote del clero secular había sido ejecutada con toda dedicación y con el consecuente reconocimiento social, cumpliendo de esta manera con el cuidado de las almas de las comunidades cristianas (españoles, criollos y mestizos) en toda la extensión del territorio salteño. Sin embargo, por una decisión personal que atribuye a la inspiración de la Virgen del Milagro, sorprendentemente a una edad avanzada para el noviciado, su rumbo se orienta hacia la Compañía, quizá motivado por la extensa actividad de conversión de los paganos que desde sus inicios con el P. Barzana había dado renombre a los religiosos jesuitas. El decreto del exilio frustró esta nueva vocación que se había despertado en el P. Francisco Ruiz de Villegas. No obstante, de sus tiempos de religioso secular, sobresale su importante rol en la difusión y consolidación en el culto de la Virgen del Milagro, que permanece injustamente olvidado y no reconocido, a pesar de haber adquirido ésta una dimensión tal que hoy es considerada una de las manifestación de fe más importante distintiva de la población norteña de nuestro país.

El P. Francisco Ruiz de Villegas, ignaciano en los últimos años de su vida, es un hijo dilecto de Salta que merece una justa revaloración y un lugar destacado en su historia. Una ciudad que durante más de cuatrocientos años fue testigo de la labor de una Orden orientada al bien común y la conversión de la fe que tuvo su punto final el 28 de junio de 2014 cuando Vicente Capuano, el último jesuita, debió abandonar la ciudad por un traslado ordenado por sus superiores, sin ser reemplazado ${ }^{33}$.

\section{Versión inédita en castellano de la biografía de Francisco Ruiz de Villegas Sacerdote}

Puesto que hasta aquí hemos escrito bastante sobre esos Hermanos que fueron párrocos de los aborígenes ${ }^{34}$, hablaremos ahora de Francisco Ruiz, cuyo elogio casi completo por una diócesis de españoles administrada por mucho tiempo con éxito, está pendiente: en efecto, en aquella función no se propuso sus propios objetivos sino los de Jesucristo $^{35}$, aquello que el Doctor de los gentiles quiere que sean cumplidos por todos y se lamenta de que no sea así.

\footnotetext{
${ }^{33}$ Casasola, 2014.

${ }^{34}$ En su obra De vita et moribus tredecim virorum paraguaycorum (en donde está incluida la presente biografía), el P. José Manuel Peramás ha desarrollado previamente las biografías de los Padres Juan Messner (Ustí, 1703 - Tacna, 1768), quien permaneció 31 años entre los Chiquitos, e Ignacio Chomé (Douai, 1696 - Oruro, 1768), que cumplió con sus funciones sacerdotales entre los guaraníes y los chiriguanos (Peramás, 1793: 184-205 y 221-263 respectivamente).

${ }^{35}$ Philippenses, 2: 21: "Porque todos buscan sus propios intereses, no los de Cristo Jesús".
} 


\section{La tierra natal de Ruiz y sus estudios de humanidades}

I. Salta (cuyo nombre está consagrado a San Felipe Apóstol ${ }^{36}$ ) está construida en un lugar muy agradable, que combina terrenos despejados y extensos con valles enfrentados rodeados por montañas. A la condición natural obedece que sea muy segura contra las incursiones de los salvajes provenientes del Chaco: en efecto, aguas pantanosas, caseríos abandonados a punto de ser reconstruidos, rodean a la ciudad por todas partes como un obstáculo eficaz; pero, como para los mortales ninguna circunstancia es feliz en todo sentido, aquella misma superficie líquida inactiva e inútil, que está en lugar de una muralla, transforma al clima en pesado y al suelo en húmedo. Todos los caminos son hermosos y rectos con espacios proporcionales, las casas son cómodas, el trabajo para los ciudadanos es abundante por el comercio que, por aquella parte, se establece con el Perú desde las jurisdicciones del Tucumán y de Buenos Aires ${ }^{37}$.

II. Esta fue la ilustre tierra natal de la familia de los Ruiz, en donde Francisco tuvo su origen, nacido el 2 de abril de 1700. Desde los años juveniles comenzó a cultivar sin interrupción simultáneamente la piedad y los estudios de humanidades: inclusive en ocasiones en que el ocio reinaba entre los escolares, para él particularmente era un descanso y un placer pasar un momento con los religiosos en su casa y permanecer en el templo. Una vez adquiridos los conceptos elementales de la cultura humana, fue enviado al colegio cordobés (cuyo renombre en Tucumán y las provincias vecinas era muy grande) por su padre, quien cuidó de que fuera admitido en el Seminario de Monserrat para que fuera educado con la disciplina más severa que allí regía la mayor parte del tiempo ${ }^{38}$.

III. Consagrado al estudio de la filosofía, luego de ser propuestos temas sobre arte a los que se dedicó para su desarrollo durante tres años, los expuso públicamente con tal éxito que le valieron las distinciones y los premios que suelen otorgarse a los que

\footnotetext{
${ }^{36}$ El 16 de abril de 1582, lunes de Pascua de Resurrección, el gobernador Hernando de Lerma fundó en la región del valle de Salta, la ciudad de Lerma del Valle de Salta, en el territorio de la región del Tucumán. Los pobladores de la ciudad, distanciados de su polémico fundador, posteriormente le cambiaron el nombre por el de Salta, añadido al nombre del apóstol San Felipe, su patrono de aquel entonces. En consecuencia, aproximadamente desde 1586 la ciudad era llamada San Felipe de Salta, reservándose el nombre de Lerma para el valle. En la actualidad, San Felipe y Santiago el Menor, apóstoles, son los patronos de la arquidiócesis de Salta y se los celebra el 3 de mayo, en tanto que el Señor y la Virgen del Milagro son los patronos de la ciudad y su celebración es el 13 y 15 de septiembre.

${ }^{37}$ Las principales rutas o sendas fueron trazadas por los conquistadores y persistieron conservadas por el uso durante el período colonial. Desde Tucumán hasta Lima había una distancia de 627 leguas y desde Tucumán a Buenos Aires 352 leguas, por lo que se organizaron un sistema de postas en todo el recorrido. Hacia el norte el comercio se concentraba básicamente en la provisión de ganado mular y vacuno, en tanto que hacia la región de Buenos Aires se enviaba suelas o cuero surtidos, bateas, objetos de madera, indumentaria y carretas.

${ }^{38}$ El P. José Manuel Peramás es autor también de la obra que lleva por título Laudationes Quinque, es decir, Cinco alabanzas en honor del muy ilustre Sr. Dr. Ignacio Duarte y Quirós, fundador del Real Colegio Convictorio de Nuestra Señora de Monserrat (1687), que fue una de las dos obras que se editaron en la imprenta del mismo Colegio en 1766. En su Introducción, en relación a la población escolar, dice: "Una cosa es cierta: después de la fundación del Colegio, el número de jóvenes de la Universidad cordobesa aumentó diez veces. $\mathrm{Y}$ a nuestro Colegio confluyen de todas partes tantos jóvenes nobles que viene a nuestro monte, ya desde el riquísimo Perú, ya desde el muy ameno Chile, desde casi seiscientas leguas de distancia para recibir, en lugar del oro y la plata dejados en nuestra casa, los frutos que nacen en este monte..." (Suárez, 2011: 4 y 5).
} 
bien lo merecen. A continuación, se abocó al estudio de la teología no sólo porque era necesario para conseguir la distinción del doctorado que anhelaba, para lo cual con frecuencia era evaluado, sino también porque a menudo competía en presencia de los profesores del colegio y de los jóvenes dedicados a la ciencia más importante hasta tal punto que siempre salió victorioso gracias a aquellas disertaciones académicas ${ }^{39}$ de manera tal que el moderador del colegio solía decir que Ruiz exponía sobre los temas de teología no según la modalidad de un discípulo sino de un maestro.

IV. Sin embargo, lo que mayor valía le otorga a Ruiz es su amor cristiano y piedad. Defensor de la filosofía cristiana, priorizó el cuidado de su espíritu al estudio de las humanidades y enseñó con su ejemplo a sus condiscípulos: muy a menudo se protegía contra los deseos de la naturaleza rebelde y las amenazas del espíritu del mal con la protección de la sagrada confesión y de la eucaristía, de donde recibía las fuerzas para imitar día a día la mejor gracia divina ${ }^{40}$. Efectivamente, los estudiantes llevaban a cabo los ejercicios establecidos de la cofradía de la Virgen María, y Ruiz no pasaba por alto ninguno de estos ejercicios. Del mismo modo cumplía con diligencia las normas del seminario y se consagraba cuidadosamente a la meditación de los hechos celestiales, a la discusión de los hechos de consciencia y a la lectura espiritual en los momentos establecidos, acudiendo luego con mucho fervor a los ejercicios de su formación que ocupaban la restante parte del día.

V. Su pasión sobresalía de manera particular cuando disponía de tiempo libre en las meditaciones sagradas de San Ignacio que todos los años eran ofrecidas por los alumnos del Seminario: en ese momento, ya que se mantenía por todos un profundo silencio y otros servían de estímulo de los restantes para apreciar profundamente las verdades eternas, en esa actividad nadie fue más solícito que Ruiz de modo que parecía no un adolescente (como lo era) sino un hombre ya maduro por la seriedad de su vida y por la honestidad de sus costumbres.

VI. En efecto, su humildad y constancia en los estudios programados de teología fueron tan sobresalientes que mereció un premio por parte del prefecto del seminario, hecho que no podría haber sido más grato a Ruiz. Se pagaban por cada alumno para su sustento cien monedas de oro (esta pensión no era gravosa allí, en donde por la abundancia de plata hay ausencia del valor del dinero). El tío paterno de Ruiz (pues quizá ya había muerto el padre) recompensaba al seminario con esa cantidad de dinero: pero éste de la misma manera que el padre imprevistamente murió. ¿Cómo reaccionó Ruiz entonces? Si regresaba a su tierra natal, se ponía en riesgo la distinción de doctor que deseaba: sin embargo, no podía permanecer en Córdoba al suprimirse el subsidio familiar.

VII. El prefecto resolvió la dificultad. Nuestro alumno Ruiz es de tal naturaleza y de tal capacidad - afirma - que se le debe hacer una concesión extraordinaria; otros aportan dinero al Seminario para ser mantenidos y educados. Ruiz, inclusive, debe ser

\footnotetext{
${ }^{39}$ En la pedagogía jesuítica, el aprendizaje de los contenidos establecidos en la Ratio studiorum se coronaba con la exposición pública de un tema. Muchas de esas disertaciones académicas tenían el formato textual de una prolusión, que eran pequeñas composiciones recitadas previamente a la defensa de una tesis con el objeto de predisponer favorablemente el ánimo del tribunal evaluador. Recientemente se ha publicado una edición bilingüe de las algunas de ellas correspondientes a la última etapa de la presencia jesuítica antes de la expulsión en el Colegio Máximo de Córdoba (Argentina) (Sánchez et alt, 2012).

${ }^{40}$ Corintios, 12: 34.
} 
mantenido por nosotros con dinero del seminario ${ }^{41}$. Finalmente, en aquellos años que faltaron para culminar la carrera de la sagrada ciencia él vivió gratuitamente. Este beneficio se grabó de tal manera en el corazón de Ruiz que desde entonces nunca se lo olvidó: comprende, entonces, que los beneficios siempre originan un rédito para el que los otorga, si el espíritu del que los recibe es agradecido. Ruiz retribuyó al seminario (cuando su situación mejoró) muchas más cosas que aquello que se había invertido en su sustento.

\section{Elegido como sacerdote de la curia administra la diócesis con santidad}

VIII. Al haber superado todas las evaluaciones de los contenidos según lo pautado, se dio a conocer su doctorado en teología y luego se inició en el sacerdocio; y no mucho tiempo después, al estar vacante una parroquia en la zona rural de Salta, se postuló y luego de resuelta la candidatura con los postulantes, fue recompensado con la cobertura de aquella vacante a los veintisiete años. Siendo ya párroco, no omitió ninguna obligación de su gran tarea para hacer a sus fieles mejores con el alimento de la palabra divina y con la administración de los sacramentos. Inclusive, para reflexionar cada vez más sobre el bien, cada año hacía venir a un orador sagrado (al que llamaban misionero), para que estimulara con piadosos sermones los espíritus inocentes hacia los deberes del amor cristiano y alejara las fuentes de los vicios y oyera a los que quieren confesarse: en efecto, esto se proponía un párroco prudente al convocar a un misionero: que los fieles acudieran a él con espíritu muy confidente y aprovecharan con bastante libertad de un criterio ajeno para los hechos de conciencia. Ojalá a menudo los encargados de las almas imitaran este ejemplo cuando los sacerdotes son escasos y quizá no hay otro en quien los feligreses confían.

IX. Presidió aquella parroquia rural por el término de siete años. Luego fue designado párroco de Salta, cuyo cargo desempeñó durante veintitrés años. En verdad, ese honor fue mayor pero también fue mayor la tarea, ya que todas las actividades de una ciudad muy noble debían ser examinadas por él en beneficio de los ciudadanos, cuyo número era muy grande. Por consiguiente, allí todo ocupaba su atención y ni siquiera durante el día o la noche albergaba otro pensamiento en su corazón, al que nada le faltaba para un sagrado ministerio. No obstante, siguiendo el precepto del Apóstol a Timoteo: presta atención a ti mismo y a la doctrina; apóyate en ellos; haciendo esto, en efecto, no sólo te pondrás a salvo a ti mismo sino también a aquellos que te escuchan ${ }^{42}$, se ocupó insistentemente en esto únicamente para que el párroco y el teólogo se aboquen al cuidado de sí mismo y de los suyos al contrario de lo que hacen algunos que prefieren ser párroco y astrónomo, párroco y geómetra, párroco y admirador frecuente de la antigüedad profana.

\footnotetext{
${ }^{41}$ El Seminario tenía previstas seis becas que habían sido establecidas por el Dr. Ignacio Duarte y Quirós, su fundador, "para los naturales de Córdoba que fuesen de mayores esperanzas de llegar después a ser unos cabales eclesiásticos: y para las demás se pagaban al Año para alimentos 170 pesos fuertes" (Page, 2012: 34). Aún después de la expulsión de los jesuitas, esta ayuda económica especial se conservó, tal como puede comprobarse en un informe del Rector de la Universidad de Córdoba Fray José Sullivan de 28 de septiembre de 1802: "Dicho Real Colegio tiene más de ochenta colegiales: de ellos por fundación sólo seis son de beca dotadas.....Para manutención de los dotados asignó el fundador el producto de una estancia nombrada Caroya...." (Chiaramonte, 2007: 12).

42 Timoteo, 4: 16.
} 
$X$. Ruiz se consagró completamente a la doctrina sagrada ya sea la que trata de las costumbres o de la religión, ya sea la que trata sobre las leyes y los decretos sagrados, ya sea la que tiene por objetivo incentivar la perfección del alma. También convocó a todos los sacerdotes de la ciudad para aprender los mismos temas o, mejor dicho, para no olvidar los conocimientos que ya habían aprendido y para debatir entre sí cada semana sobre los objetivos de los hechos buenos y malos para beneficio de una correcta explicación de los asuntos con los que se reflexiona sobre una conciencia que debe ser correctamente orientada. Ruiz en persona estaba al frente de este ejercicio doctrinal.

XI. Además de esto, aplicaba de manera permanente las enseñanzas que había extraído de los libros para la vida cotidiana con el objetivo común de recibir las confesiones, formar a los ciudadanos y ayudar a los enfermos con una obra igualmente humana y divina. Se preocupaba con el mayor cuidado de que nadie cometiera algo indigno con el testimonio cristiano, superando cualquier obstáculo, en caso de que ya no hubiera oportunidad para las buenos consejos y la benevolencia. Del mismo modo, insistió constantemente para que sus fieles de los días domingo se reunieran a la tarde para escuchar las explicaciones de la ley y los ministerios. También a menudo indujo a otro de los magistrados de la ciudad a que, mientras se desarrollaba la catequesis, él mismo recorriera los caminos y a los que encontraba inactivos por el ocio o con tiempo libre por el juego, los persuadiera de entrar en la cena ${ }^{43}$ con la cual el alma se nutre con alimento celestial. Si alguien se abstuviera sin una causa justa, luego lo reprendía o incluso, si era esclavo, procuraba que fuera castigado por el amo.

XII. Era también muy severo y cuidadoso para que el ritual de la Pascua sea bien acatado por todos. Y aunque muchos fieles habitaban lejos en el campo según la costumbre y se les debía permitir que permanezcan en el templo con el fin de recibir los sacramentos, no obstante, él personalmente exigía rigurosamente el compromiso recibido de la santa confesión y de la eucaristía, no teniendo consideración por ningún infractor o demora en este asunto quienquiera que sea, indigente, rico, plebeyo o noble: en efecto, quería no sólo ser sino ser tenido por un administrador fiel ${ }^{44}$ y un pastor, y no un mercenario que huye o un perro mudo que no es capaz de ladrar.

\section{La caridad de Ruiz para con los pobres}

XIII. Ya que el ejemplo es un camino muy breve para la enseñanza de los otros, Ruiz siempre precedió a sus fieles en la práctica de las virtudes. Todos los años (mientras otros se hacían cargo del cuidado habitual de la parroquia) se retiraba al colegio de los jesuitas para meditar las verdades eternas lejos del pueblo y allí mismo se reunía con otros sacerdotes a quienes había invitado amablemente, recordando muy bien que los hombres dedicados al templo son la sal de la tierra y el fermento del pueblo y tal materia prima y las costumbres de los ciudadanos servirán como la esencia del fermento y de la sagrada sal. En efecto, durante todo aquel período de ocho o nueve días disfrutaba del tiempo libre para sí mismo y para los asuntos del alma, excluidas así las ocupaciones urbanas.

XIV. Sin embargo, no era tan austero como para prohibirse a sí mismo o a los otros alguna distracción. Recibía en su casa a algunos hombres honestos por la tarde

\footnotetext{
${ }^{43}$ Lucas, 14: 22.

${ }^{44}$ Ibíd, 12: 42.
}

144 Juan Pedro Kalinowski. Versión inédita en castellano de la biografía ... 130-157. 
para conversar alegre y moderadamente. Inclusive, luego de una oportuna distracción, completaba la conversación con la lectura breve de un libro piadoso para recobrar también la salud del cuerpo. Dedicaba el resto del tiempo al estudio de las cosas útiles. Evitaba aparecer públicamente, salvo que la función del sagrado ministerio lo obligara, y se mantenía lejos en la medida en que podía de las casas de los ricos. Por el contrario, en cualquier lugar y siempre que estaba libre, estaba presente junto a los pobres, pues para con ellos se había provisto con lo más íntimo de la misericordia.

XV. En la ciudad no había una casa de huérfanos pero la casa de Ruiz, quien era el padre común de los desposeídos, existía para los huérfanos. Si algunos eran expuestos junto a las puertas de aquélla, ya sea por vergüenza o por la pobreza apremiante de los padres, él mismo los llevaba consigo y les proporcionaba alimento y luego se preocupaba en educarlos hasta que tenía la edad y el criterio para que pudieran fácilmente tomar decisiones por sí mismos. En cuanto a las jóvenes indigentes les daba una dote y de manera secreta desde hacía tiempo les distribuía una limosna para quienes no eran capaces de cavar y se avergonzaban de mendigar ${ }^{45}$. Entre los infortunados de esta clase existió cierto caballero que, perdidas las riquezas, casi moría de hambre. A éste (para que no pidiera con vergüenza el sustento de otros) todos los días Ruiz lo llamaba a su mesa con una constancia tal que, cuando salió de Salta, dejó una cierta suma de dinero, con la cual se pudiera abastecer de alimento a aquél.

XVI. Por lo menos existen dos testimonios distintos de este tipo. Una desdichada mujer yacía convaleciente, con los nervios de los pies y de las manos distendidos. Luego de recibirla en su casa, le dio un lugar para dormir y sirvientes para que la cuidaran. La larga enfermedad le otorgó una ocasión inmejorable y una posibilidad de ejercer la paciencia a Ruiz. Aquélla era bastante lenta, ya sea por el defecto de su condición física o de su salud, y bastante quejumbrosa y para el dueño de la casa no poco molesta y difícil de tratar: sin embargo, Ruiz de manera tenaz toleró todas las quejas para consigo hasta que los sufrimientos consumaron su muerte y fue sepultada sin gastos por el Párroco que gratis la había alimentado. En efecto, Ruiz también era generoso en este aspecto de tal modo que al haber conocido en el desempeño de su ministerio a quienes con dificultad podían pagar una suma fijada por la ley con motivo de la escasez del patrimonio familiar, a ésos con gusto les perdonaba la deuda.

XVII. Este otro hecho es digno de ser recordado. Cierta mujer dio a luz una criatura tan deforme con pies y manos inclusive en la mitad del cuerpo que se pensó que no dio a luz a un niño sino a un monstruo: sin dudarlo lo echó de su casa. La partera más clemente que su madre lo depositó junto a la puerta de Ruiz para que éste decidiera qué hacer. Cuando lo vio tendido, se preguntó si sería una fiera o un ser humano al mismo tiempo; pero por el rostro, que era perfecto, comprendió que era humano, lo bautizó y le trajo algo para comer.

XVIII. ¿Qué más añadir? Aquel creció y quien era tan defectuoso en cuanto al cuerpo, mostró una inteligencia aguda y desarrollada. Ruiz incentivó su inteligencia. El niño tenía sólo dos dedos para tomar la pluma. Por este motivo, Ruiz, que estaba habituado a su uso, enseñó a escribir a su alumno ya capacitado anteriormente para leer. Cuando fue más grande, le enseñó lo vinculado al dinero para ponerlo al frente de una taberna. Y, en efecto, corrigiendo aquél los defectos de su condición natural con la actividad comercial, incrementó su patrimonio y mantuvo el sustento para sí y para su ma-

${ }^{45}$ Ibíd, 16: 3.

145 Juan Pedro Kalinowski. Versión inédita en castellano de la biografía ... 130-157. 
dre (quien finalmente se dio a conocer) de manera independiente y piadosamente e hizo esto con la mayor alegría y satisfacción de Ruiz, que amó a éste antes que a los otros diciendo que él había sido encomendado por Dios para el exclusivo ejercicio de la caridad.

XIX. Además, para cuidar no sólo a los presentes sino también para velar por los que vendrán y por los que están alejados construyó una residencia nueva y cómoda para los párrocos sucesores, es decir, añadió esta acción a su habitual bondad. Para estas residencias y otras obras útiles de este tipo se invirtieron las rentas del sacerdote, bajo la supervisión del mismo Ruiz, de modo que fueran suficientes para tantos gastos, y no se encontró otra fuente de recursos de donde proveerse que aquella que nunca se acaba: dad, y se dará a vosotros ${ }^{46}$.

\section{La compasión espiritual del párroco Ruiz}

$\mathrm{XX}$. Los hechos que fueron descritos hasta ahora se refieren a las acciones que se vinculan con el cuerpo. Sin embargo, también existe la caridad espiritual para combatir las inquietudes del alma hacia las que los Párrocos por su función se han visto comprometidos en gran medida. Ruiz se ofrecía generoso e indulgente a los que se le acercaban y nunca le faltó a nadie ni consejo ni recursos. Si ocasionalmente se percata de que alguien con un ejemplo indeseable ha ofendido a otros, no suspendía su actividad hasta que levantaba la piedra de en medio del escándalo y aportaba una solución al problema. De la misma manera, con predisposición de espíritu actuaba de manera discreta para recomponer los pleitos, anular las enemistades y reconciliar las diferencias. Y tenía tanta destreza para resolver los problemas que si alguna dificultad compleja se producía, el obispo, el gobernador, los cónsules (que llaman Alcaldes) lo consultaban para dar una resolución sin violar la justicia ni la equidad. Por esta razón, se difundía entre todos una gran reputación sobre Ruiz, por la que él no se enorgullecía en nada, como modesto y humilde que era.

XXI. Los amigos y familiares, al destacarse por tantas virtudes intachables, eran los promotores de escribir a los administradores de las actividades sagradas en la iglesia de modo que, al exponer sus tareas de muchos años y sus méritos, se tenía un motivo para nombrarlo en algún episcopado o, en todo caso, un canonicato y, además, daban el testimonio de su obra para una justa petición; pero nunca convencieron de eso a Ruiz que ni siquiera (lo que era muy fácil) hizo algo para que se le asignara otra parroquia más opulenta. Sin embargo, no pudo eludir lo que no sólo el comisario (como lo llamaban) de la Bula de Cruzada ${ }^{47}$ sino también el Examinador habían resuelto conforme a las decisiones sinodales.

\footnotetext{
${ }^{46}$ Lucas, 6: 38.

${ }^{47}$ La Bula de la Santa Cruzada es un documento pontificio que el P. Ladislao Orosz la define como "Letras Apostólicas munidas de un sello de plomo que contienen muchas gracias que la Sede Apostólica concede a los que cooperan para la extirpación de los infieles, ya sea combatiendo personalmente, ya mediante oraciones y limosna" (Orosz, 2002: 102). Su primera aplicación se remonta al papado de Alejandro II en 1064 y con el paso de los años terminó convirtiéndose en una renta muy segura y estable para la Corona para hacer frente a sus obligaciones. En su aplicación, dado lo complejo y delicado de su instrumentación en las poblaciones americanas, debían intervenir tanto los miembros de la Iglesia como funcionarios administrativos reales. Para muchos jesuitas, la aceptación de las gracias de la Bula suponía una relajación espiritual o connivencia con cierto comercio espiritual (Benito, 1996: 75).
} 
XXII. Por aquella época, un hombre noble y conocido de Salta con el cargo de Abanderado del Rey (que era una distinción muy honorable) Buenaventura Caravajal ${ }^{48}$ al sentir que se moría instituyó como heredero universal a Ruiz (tanta autoridad e integridad tenía para aquél) a fin de procurar edificar una casa para las mujeres, cuyo pudor y honestidad carecieran de refugio o de protección: cuidó, inclusive, en el testamento que, si el mismo Ruiz considerara que otra obra podía ser más útil, la pudiera hacer libremente y sin ningún cuestionamiento. Ruiz inmediatamente puso mano a la obra para construir un edificio en beneficio de aquellas mujeres que debían recibir asilo. Pero al llegar por casualidad a sus manos un libro que desarrollaba la educación de las Vírgenes Sagradas ${ }^{49}$, para quienes en la doctrina cristiana existe la preocupación de instruir a las niñas en quehaceres femeninos, cambió de parecer y pensó que esto sería lo mejor para Salta, y con empeño destinó su tiempo a construir un colegio para aquellas jóvenes merecedoras de una educación pública en la ciudad. Y efectivamente hubiera concretado su obra si no se hubiera debido marchar luego de ese lugar por la ley del exilio de la que luego hablaremos.

\section{El sentido religioso de Ruiz}

XXIII. Habiendo conocido muy bien Ruiz que toda buena dádiva y todo don perfecto viene de lo alto del padre de las luces ${ }^{50}$, era constante al evocar la ayuda de Dios y los Santos. Cada día ofrecía la hostia sagrada para pedir y recibir los más abundantes recursos por parte del creador manifiesto de todo favor para asumir las responsa-

\footnotetext{
${ }^{48}$ El abanderado o porta estandarte era la persona que llevaba el emblema, insignia o estandarte usado como símbolo visual de la casa real.

${ }^{49}$ La orden religiosa de la Virgen María en pos de la educación de las jóvenes (los españoles la llaman Doctrina de la Esperanza) que aprobó Paulo V el 7 de abril de 1607 fue difundida exitosamente por su fundadora Juana Lestona, nacida en una tierra muy noble, en Francia. Trasladadas luego a España las órdenes religiosas, en Barcelona fue fundado un primer colegio. Luego, de otras ciudades fueron trasladadas las mismas devotas de la Virgen que navegaron hasta América Septentrional y también estuvieron a punto de viajar hasta la Meridional. Sin duda, puesto que aquella organización es completamente útil (como consta por sus frutos) para todas las provincias, del mismo modo sería muy útil para las ciudades del Nuevo Mundo. No es que las madres de familia no puedan educar a las hijas en el hogar; sin embargo, están dedicadas a otros quehaceres y a su numerosas descendencias a las que quieren mucho y a las que más allá de lo conveniente perdonan con desmedida indulgencia sus errores. Sin embargo, mucho interesa si una inocente educación transforma a las jóvenes religiosas a las que Dios ofrece una oportunidad única para este objetivo o si a menudo están incapacitadas para esta vocación por otras obligaciones, ya que ha sido correctamente establecida para el bien de la ciudad en un momento muy importante. Aquellas jóvenes, dispuestas a numerosas labores por su cantidad, su edad y el avance de sus niñas, les enseñan con dedicación a leer, escribir, cantar piadosamente, elevar plegarias de acuerdo con los ritos, tejer, coser, bordar y las restantes actividades que son propias del sexo débil y (lo que es más importante) reintegran a su hogar a las niñas dotadas de pudor, modestia y buenas costumbres (a la luz de los ejemplos de la Virgen María, a quien invocan a cada momento) e igualmente instruidas en la doctrina cristiana y provistas de un sobresaliente amor cristiano, retornan a su hogar a donde no veo que los padres puedan ser capaces de elegir para sus hijos algo mejor y más digno.
}

Y por esto es evidente con qué acierto Ruiz se decidió a construir un hogar y una residencia permanente en Salta con maestras experimentadas para las niñas; en efecto, si una inocente joven es educada desde los primeros años con rectitud, apenas habrá luego quien conservando la honestidad y evitando los peligros comunes de los jóvenes, se dedicará a la labor doméstica deseosa de una casta soledad, más aún, "buscando la lana y el lino trabajará con la armonía de sus manos y con sus dedos tomarán el huso y no comerá el pan sin haber trabajado y respetando a Dios, será elogiada ella misma personalmente (Prov. c. XXXI)" (Nota del autor).

${ }^{50}$ Santiago, 1: 17. 
bilidades de su función según las normas. Del mismo modo, guiaba con el ejemplo a los otros sacerdotes para que se tuviera el debido respeto en las actividades sagradas y los rituales divinos sean ejecutados de manera piadosa. A menudo, además, él mismo meditaba consigo mismo en su residencia para que su espíritu por la cantidad de ocupaciones, no se sintiera agotado, como sucede, y se opaque el brillo recibido de las virtudes. Siempre siguió al Apóstol de las Indias San Francisco Javier con deferencia singular. Durante treinta años cuidó que se celebre su día de fiesta con una ceremonia solemne con actividades en su honor y, ya que se había generalizado las novenas de los santos cerca del comienzo del mes de marzo de todos los años, entonces, organizaba los ceremoniales todos los días nueve para el más importante, repartiendo generosamente todos los elementos que eran necesarios junto al altar.

XXIV. Y no satisfecho con aquellas acciones, al estar los territorios de Salta expuestos a las incursiones de los salvajes, convenció al Cabildo y al pueblo de Salta que adopten a San Javier como otro protector de la ciudad (primero están San Felipe y Santiago Apóstoles ${ }^{51}$ ), establecida su ceremonia el 3 de diciembre, que es una día consagrado al Santo, e incorporada gracias al pedido público de las administraciones de las ciudades y de los hombres religiosos. También consiguió de una junta militar que lo invocaran como su protector en los enfrentamientos militares. Y a San Javier no le faltaron ofrendas de los nuevos devotos: la audacia sin límites de los salvajes fue contenida antes de que ellos se dispersaran en todas direcciones de manera impune y si en ocasiones se libró un combate, con la protección del divino guía, la victoria se alcanzó gracias a un piadoso ejército.

XXV. Pero la mayor fidelidad y amor de Ruiz lo dirigió a María madre de Dios. La había elegido como su protectora ya desde sus jóvenes años, en especial cuando en el Seminario de Monserrat bajo su tutela comenzó y terminó sus estudios humanísticos más importantes ${ }^{52}$. En su tierra natal, ya Párroco, desde un templo al cual presidía, promovió las ofrendas y el culto hacia la madre sobresaliente, aprovechando esa circunstancia favorable. Dijimos en la vida de Manuel de Vergara ${ }^{53}$ que la profunda religiosidad de los salteños se reflejaba en la sagrada imagen de la Virgen del Milagro. Ruiz, para estimular cada vez más los sentimientos piadosos de los ciudadanos, pidió supli-

\footnotetext{
${ }^{51}$ Cfr. nota $n^{\text {o }}$ 33. En la actualidad, San Bernardo Abad también es considerado patrono de la ciudad de Salta y su fiesta se celebra el 20 de agosto.

${ }^{52}$ El especial afecto y culto de la Santísima Virgen fue una devoción muy extendida entre los hermanos de la orden jesuítica. En la biografía de Vicente Sans, el P. Peramás señala que en Buenos Aires y en Córdoba muchos exclamaron al enterarse de su muerte, acaecida el 4 de diciembre de 1787: "Ya murió el devoto de la Santísima Virgen: ha muerto el propagador de la devoción a María Santísima (Peramás, 1791: 242). E inclusive en la vida del P. Manuel de Vergara, al que se alude en este parágrafo, el biógrafo catalán le atribuye la composición en lengua española de doce oraciones correspondientes a los doce días en los que se expone las doce virtudes de la Virgen: fe, esperanza, caridad, piedad, humildad, pobreza, castidad, obediencia, oración, mortificación, silencio y modestia (Peramás, 1791: 54). Y una consagración a la Virgen semejante a la experimentada por el fundador de la Orden San Ignacio de Loyola relata el P. José Peramás que experimentó Ignacio Duarte y Quirós cuando la elige como patrona y como inspiración para el nombre del nuevo Colegio que estaba por fundar (Suárez, 2011: 5).

${ }^{53}$ En el desarrollo de la biografía del P. Vergara, José M. Peramás describe que, en ocasión de producirse un terremoto el 13 de septiembre de 1692, los habitantes de Salta sacaron del templo una imagen de la Virgen María para implorar su ayuda y la colocaron en medio de la plaza, momento a partir del cual la tierra se calmó. A partir de ese suceso, la denominaron Virgen del Milagro y su adoración se consolidó con el paso del tiempo entre los salteños, especialmente cuando recibieron noticias de que la ciudad de Esteco, situada a cincuenta leguas de distancia, fue destruida completamente, muriendo todos sus habitantes (Peramás, 1791: 35).
} 
cante a través de cartas y obtuvo del Papa Clemente XIII ${ }^{54}$, en favor de las faltas cometidas por los pecadores, un completo perdón en aquellos tres días, por lo que a mediados de septiembre con la devoción más piadosa y con la súplica pública de los arrepentidos, la ciudad entera se reúne para refugio de los pecadores ${ }^{55}$.

XXVI. Además de eso, no dejando de lado nada que pueda propiciar un cambio saludable de las almas, recordaba a los fieles que estaban en deuda por los numerosos beneficios recibidos de la Reina de los cielos, con cuya asistencia en otro tiempo la frágil Salta se mantuvo firme, ya que ciertamente sólo subsiste el nombre de Esteco ${ }^{56}$ (que en aquella misma oportunidad desapareció por completo), pero no la ciudad junto a todos sus ciudadanos desaparecidos a quienes con su boca abierta la tierra los tragó con sus casas, sus tiendas y todas sus pertenencias ${ }^{57}$.

XXVII. No sólo con palabras (cosa que es fácil) sino también con hechos exhortaba a los ciudadanos. Por iniciativa propia celebraba el día más importante de los tres días conmemorativos. Es más, también hizo que en cada tercer día de fiesta de todos los años (tal vez se produjera en el tercer día de fiesta aquel terrible terremoto, hecho que ahora no hay posibilidad de calcular a partir de los registros de los acontecimientos) se realice un solemne acto sagrado en acción de Gracias. Pero puesto que para esta ceremonia serían costosos los cirios y demás elementos, mientras estuvo presente, dispuso todo lo necesario de manera generosa y para que estando ausente la piadosa ceremonia no se interrumpa, cuidó que dos caballeros instrumentaran un tributo para esta obra.

\section{Se encamina hacia la Compañía}

XXVIII. Verdaderamente, la Virgen María recompensó, además, a su fiel devoto dedicado a su culto con un beneficio que Ruiz juzgó como el más importante de todos. En aquel día del triduo dedicado a su celebración, en el que señalamos que Ruiz acostumbraba a elevar plegarias con más fuerzas a la Virgen del Milagro, orando en el templo, sintió el deseo de ser estimulado a la mayor perfección para complacer mejor a Dios y a la madre de Dios: en ese momento, le pareció escuchar en el interior de su co-

\footnotetext{
${ }^{54}$ Clemente XIII (Venecia, 1693 - Roma, 1769) fue elegido como un Papa de posición más amigable con la orden de los jesuitas y su gestión se desarrolló en un clima cada vez más hostil a la fe, a la Iglesia y al papado mismo. Debió enfrentar graves crisis con la corona portuguesa cuando en 1759 publica un decreto real deportando o encarcelando a todos los jesuitas como traidores y con la corona francesa, cuyo tribunal de Paris el 11 de agosto prohíbe la Compañía de Jesús en Francia como paso previo a su disolución de 1764 decretada por Luis XV, en tanto que en España Carlos III concretó la expulsión el 1 de abril de 1767. Clemente XIII cuando estaba a punto de tratarse la supresión de la Orden, sufre un ataque al corazón y muere (O’Neill y Viscardi, 2001 (III), 2998).

${ }^{55}$ Refugium peccatorum es una de las cuatro advocaciones asociadas a la Virgen María en la Letanía de Loreto, que data de 1558, y fue aprobada en 1587 por el Papa Sixto V. Las otras son Salus Infirmorum (sanadora de los enfermos), Consolatrix afflictorum (consuelo de los tristes) y Auxilium christianorum (ayuda de los cristianos).

${ }^{56}$ La ciudad de Esteco se fundó en 1609 a partir de los habitantes sobrevivientes de las ciudades de Nuestra Señora de la Talavera (fundada en 1568) y de la ciudad de Nueva Madrid de las Juntas (fundada en 1592). Su decadencia comenzó a finales del s. XVII por quedar apartada de nuevas rutas comerciales españolas, los ataques constantes de los salvajes y un terremoto que en 1692 acabó definitivamente con ella.

${ }^{57}$ Deuter. c. XI, sobre la destrucción de Dathan y Abiron (N. del A.).
} 
razón: “ingresa a la Compañía de Jesús" "58 . En efecto, creyó que esa voz fue enviada del cielo y regresando a su residencia (para que ese deseo ardiente no sufriera una demora) envió desde allí una carta al prefecto de los jesuitas en las que solicitaba que sea admitido entre los hermanos.

XXIX. El prefecto, puesto que Ruiz tenía ya demasiada edad, estimó oportuno consultar al prepósito general sobre cómo proceder por esta circunstancia ${ }^{59}$. El general respondió que lo admitiera, ya que podía estar libre en ese momento para los sagrados ministerios una vacante de un noviciado. Por consiguiente, el moderador de la provincia respondió a Ruiz que fuera, con Dios como promotor y guía, a la residencia cordobesa de los novicios. Esta carta se envió a Ruiz que participaba personalmente en el día festivo de la Virgen del Milagro (ya había transcurrido un año, pues Roma está situada a mucha distancia de la Provincia del Paraguay); este hecho, que fue llevado a cabo por su protectora con afecto y deliberadamente, fue muy grato para el piadoso creyente.

XXX. Apenas lee Ruiz aquella carta muy esperada por mucho tiempo del Moderador cuando, después de organizar las actividades de su residencia y de su templo, partió hacia Córdoba (luego de ocultar el motivo de la partida a causa de su amor y bondad para que ninguno de los ciudadanos sufriera algún contratiempo) y allí, tras cumplir con todos los requerimientos según lo establecido con el Obispo, luego de abdicar de la parroquia, ingresó como novicio el 22 de diciembre de 1758 (que es el día de la Virgen María en el que se consagra el templo), siendo recibido por el mismo Ilustrísimo Señor Pedro Miguel de Argandoña ${ }^{60}$, quien frente a los jesuitas reunidos en la capilla doméstica pronunció un discurso elogioso sobre los méritos y los elogios de Ruiz, no sin la gran vergüenza del flamante novicio, que se consideraba a sí mismo de otra manera.

XXXI. Sin embargo, mientras se entonaba aquel himno del rey que inspiraba placeres sagrados: este es mi reposo por los siglos de los siglos; aquí habitaré puesto que lo eleg $\imath^{61}$, un gran rumor había en Salta y una gran sorpresa por parte de los ciudadanos que consideraban entre ellos que un hombre de edad, después de tantos años de administrar una noble y próspera parroquia con rectitud y prudencia, haya renunciado imprevistamente a pesar de la celebridad de su nombre, especialmente en esa época, en la que el prestigio de la Compañía en todas partes se destruía con acciones infamantes ${ }^{62}$.

\footnotetext{
${ }^{58}$ Hay que recordar que San Ignacio de Loyola tuvo una gran devoción por Nuestra Señora de Monserrat y la tradición señala a la Virgen como la impulsora de su consagración a la vida religiosa.

${ }^{59}$ La edad media en la que los jesuitas entraban a formar parte de la orden ignaciana se sitúa en torno a los 18 o 19 años, ya que el período del noviciado era una etapa fundamental en la formación del jesuita que se complementaba con la adquisición de conocimientos teóricos y prácticos acordes a las labores de la Compañía de Jesús que podía llegar a prolongarse por un período cercano a los 15 años (Martínez Tornero, 2014: 736).

${ }^{60}$ Pedro Miguel de Argandoña Pastene Salazar (Córdoba, 1693 - Charcas, 1775) fue Obispo de Tucumán entre 1745 y 1762 y arzobispo de Charcas entre 1763 y 1775. Luego de la creación de la diócesis de Córdoba del Tucumán el 14 de mayo de 1570 por San Pío V (Bula Super specula militantes Ecclesiae) con asiento en Santiago del Estero, el Papa Inocencio XII en 1699 trasladó la sede episcopal a Córdoba y el paso del Obispo Pedro Miguel de Argandoña por esta ciudad estuvo marcado por tres hechos vinculados entre sí: la conclusión de la catedral en 1756, la celebración del sínodo diocesano y la fundación del Seminario Conciliar de Nuestra Señora de Loreto y Santo Tomás, cuya nueva planta se concluyó en 1758 y contaba con nueve colegiales (Vergara, 2005: 284).

${ }^{61}$ Salmo, 131: 14.

${ }^{62}$ Francisco Javier Miranda (Ledesma, 1730 - Faenza, 1811), en el parágrafo 204 de su obra El Fiscal Fiscalizado, confirma la apreciación del biógrafo de Ruiz de Villegas al explayarse de la siguiente manera: "La máquina para la destrucción de la Compañía de Jesús se había arquitectado en Francia en el Con-
} 
En realidad, si consideraras la reciente decisión de Ruiz aislada de un momento de racionalidad humana, apenas la aprobarías a no ser que la aceptaras que fue inspirado por la Virgen ${ }^{63}$. ¿Por qué, pues? ¿Decidía dedicarse al bienestar de los prójimos y a la perfección (de que era objeto la Compañía) de sí mismo y de sus semejantes? No obstante, el párroco hacía esto por el mayor bien de sus fieles. Por consiguiente ¿Con qué fin el encierro de un aislamiento religioso se anteponía a los fines de una gran parroquia?

XXXII. En efecto, pienso que esta circunstancia puede ser considerada de manera excepcional, porque, como dicen, para Ruiz los hechos divinos siempre actuaron juntos de manera favorable, en beneficio de su función específica se le concedió desde el cielo que ejerciera en el último período de su vida difíciles ocupaciones para atesorar una mayor cantidad de méritos para sí y resplandeciera igual que el oro en el horno ${ }^{64}$. Le ocurrió a Ruiz, en efecto, lo que se ha dicho sobre el óptimo Tobías: puesto que habías sido aceptado por Dios, fue necesario que la tentación te pusiera a prueba» ${ }^{65}$. Pero cualquiera que haya sido el motivo de este hecho que no nos está permitido indagar, el anciano Ruiz (tenía 58 años) comenzó de alguna manera a ser niño de nuevo entre los jóvenes novicios y a desear ardientemente la leche espiritual pura ${ }^{66}$.

XXXIII. Se mantuvo entusiasmado y predispuesto frente a todas las exigencias que trae consigo la formación religiosa y que el maestro disponía. Sin embargo, como sobresalía por la madurez de su criterio sobre los restantes novicios, era bastante modesto con ellos, servicial y humilde y respetuoso del silencio y dedicado a las tareas de la

sejo o Sinagoga de los jansenistas, de los filósofos y de los libertinos y ateístas prácticos y según el plan allí establecido el primer movimiento de la maquina debía hacerse en España con la expulsión de los jesuitas. Esta se intentó sorda y lentamente en el Reinado de Fernando VI. Para preparar las cosas y disponer el golpe, se inventó el ruidoso tratado de la Línea divisoria de límites en la América Meridional entre las Coronas de España y de Portugal, de cuya ejecución se preveían y se deseaban los disturbios del Uruguay; disturbios que habían de conducir infinitamente para la expulsión proyectada de los jesuitas de España y de Portugal. Con el mismo fin se inventaron las medallas o monedas por un fraile (cuyo nombre y orden callo por caridad y por respeto a su religión) con la efigie del Rey Nicolás I, jesuita, por un lado, y con el nombre de IHS por el revés: monedas que se atrevieron a presentar a aquel monarca para persuadirle que los jesuitas le usurpaban a cara descubierta la soberanía en la América acunando moneda con la imagen del nuevo rey jesuita, alzado por ellos en el Paraguay. Al mismo fin se estampó y divulgó por toda Europa y se envió a todas las cortes el libelo infame intitulado Relación abreviada de la República del Paraguay. Estas negras y calumniosas invenciones empezaron a hacer alguna brecha en el corazón de aquel religioso soberano, de cuyo lado lograron apartar primero al Marques de la Ensenada, uno de los mejores Ministros que ha tenido el Reino de España, y después al "real Confesor jesuita" Francisco Rábago; mas no tardaron mucho en disiparse estas calumnias. Murió Fernando VI, por cuya disposición quedo de gobernadora del reino la reina doña Isabel Farnese, madre de Carlos III hasta su transmigración de Nápoles a España. Proseguían los maquinistas su infernal juego pero un contratiempo desconcertó por entonces su designio cuando aquella gran reina descubrió con su penetración la trama de inicuísimas calumnias imputadas a los jesuitas, las cuales la obligaron a declararse tan fuertemente por ellos que hasta que cerró los ojos no esperaron sus mortales enemigos poder conseguir nada contra la Compañía en España" (Miranda, 2013: 268).

${ }^{63}$ El cambio de la persona verbal efectuado por el P. José Peramás obedece a la figura retórica denominada apóstrofe que consiste en dirigirse durante un discurso o narración a un interlocutor (real o imaginario) desde la perspectiva del orador o escritor a los fines de acortar la distancia entre emisor y receptor y aumentar así la receptividad del mensaje.

${ }^{64}$ Sapientia, 3: 6.

${ }^{65}$ Tobías, c. XII, v. 13 (N. del A.).

${ }^{66}$ Las palabras latinas son una paráfrasis de la Primera Carta del Apóstol San Pedro (2, 2): Quasimodo geniti infantes, rationabile sine dolo lac concupiscite, ut in eo crescatis in salutem: como niños recién nacidos, desead la leche espiritual pura, a fin de que, por ella, crezcáis para la salvación. 
residencia, a servir en el comedor, a reprimir la dura inclinación del cuerpo y a cultivar con ejercicios frecuentes las virtudes de su alma. Para éstas, el espíritu de aquél se mostró siempre dispuesto, por más que a veces su cuerpo haya sido débil; en efecto, estaba al alcance del corregidor de hermanos para conversar con él en el interior del templo. Despreciaba los antiguos honores, aunque ahora llevaba una vida tranquila como uno de tantos, rechazaba las comodidades de una habitación confortable, aunque ahora vivía con estrechez; aceptaba una comida frugal y escasa en lugar de una abundante y variada.

XXXIV. Este cambio de costumbres era bastante riguroso para un hombre mayor; sin embargo, por el contrario, se mantenía firme como un hombre joven y llevaba con gusto la cruz que había aceptado según su voluntad para seguir a Jesús Crucificado. Cumplido ya los dos años de noviciado según la costumbre de la Compañía, tomó los votos religiosos y a las pertenencias que mientras era novicio no se podían vender, las destinó a obras piadosas; no obstante, a los libros que había empleado los ofreció como donación al Colegio de Salta $^{67}$ y no conservó ninguno para sí y luego vivió pobre verdaderamente durante el resto de su vida.

XXXV. Cultor sobresaliente de la obediencia, no anteponía su voluntad a la de sus Superiores ni era remiso a cumplir aquello que le parecía un precepto en una ocasión de la cual luego hablaremos. En primer lugar, fue destinado a ir al Colegio de San Miguel de Tucumán ${ }^{68}$ y a cumplir allí su sagrado deber, obligación a la que se dedicó con empeño (ya que hacía tiempo que tenía experiencia en tratar los asuntos del espíritu). De allí, fue enviado a Salta (puesto que el Gobernador de la provincia lo quería junto a sí y no podía oponerse al que lo solicitaba), luego de haber puesto bastante resistencia y haber solicitado el mismo Ruiz que no fuera regresado a su tierra natal, inclusive que fuera desplazado en poco tiempo de todos los colegios. Pero en vano elevó abundantes súplicas. Obedeció y se dirigió a la ciudad capital y desempeñó una serie de actividades conjuntas, dando ánimo, escuchando las confesiones y administrando la ayuda sagrada a los enfermos de sus fieles que recordaban la caridad y cuidado del Párroco y se ocupaba de su santidad y perfección.

\section{Es desterrado a Europa}

XXXVI. He aquí que inesperadamente las obras sagradas se debieron interrumpir. Entre los jesuitas salteños el decreto del exilio fue notificado el 3 de agosto de 1767. Durante este tiempo Dios había conservado a Ruiz y lo había ligado con los vínculos religiosos de tal modo que cuando era joven se vestía e iba a donde quería, alcanzando

\footnotetext{
${ }^{67}$ La casa de la Compañía de Jesús de Salta, que llevó el nombre de Colegio, fue fundada en 1596 por el P. Juan Romero (Sevilla, 1560 - Santiago, 1631), superior de los jesuitas en Tucumán, y luego construyó una pequeña residencia en Jujuy años después (Toscano, 1907: 61).

${ }^{68}$ Los jesuitas construyeron su Colegio e Iglesia de Santa María Magdalena en Ibatín, gracias a una donación del Deán Francisco de Salcedo efectuada en 1613 y luego fue trasladado en 1685 a San Miguel de Tucumán e incorporaron también numerosas tierras por donaciones, transacciones o compras. La explotación de esas tierras permitía el desarrollo del Colegio tanto en sus actividades educacionales como en el progreso de sus bienes materiales. Entre 1690 y 1695 fue rector el P. Diego Ruiz quien concluyó el traslado a la ciudad de San Miguel y en 1765 el P. Francisco Frasset estuvo a cargo del rectorado. Realizó un inventario del patrimonio El libro Matriz de los bienes del Colegio, que se utilizó para verificar el que se hizo en el momento de la expulsión de los jesuitas de Tucumán. En ese momento crítico, el rector fue el P. Joseph Sánchez, que había sido profesor del Colegio Máximo cordobés (Peña de Bascary, 2006: 8).
} 
la ancianidad iba a donde no quería ${ }^{69}$. Ningún hecho más triste y lamentable le había podido suceder a causa de tal infortunio de la Compañía y de tanta infamia. Él, en efecto, podría haber acudido a la Virgen del Milagro con fortaleza de ánimo con la intención de pedir firmeza de carácter y alivio para su profunda tristeza; sin embargo, al estar ocupado el Colegio con gente armada, no se le permitió dar un paso a nadie fuera de la residencia: no obstante, luego de preparar rápidamente los víveres, al día siguiente fue obligado a subir al transporte que lo conduciría a Buenos Aires.

XXXVII. El camino de Salta hacia la ciudad a la que ahora nos referiremos, tiene una extensión de 300 leguas. Ruiz hizo este viaje a los 66 años de edad encerrado en un medio de transporte que durante el día era el carro en donde se viajaba y en la noche el dormitorio en donde se dormía, pues en aquellos lugares desolados no existían hospedajes. Por esta razón, no obstante, la paciencia de Ruiz y de los compañeros de viaje era exigida cada vez más, y el camino que se debía emprender resultó una circunstancia intolerable. Ningún otro objeto les había sido permitido sacar del colegio a los hermanos más que algunos libros sagrados, la indumentaria indispensable que estaba guardada en pequeños arcones, y el lecho que estaba extendido en medio del carro.

XXXVIII. El gobernador (callamos su nombre, solamente decimos que es aquel mismo que había convocado junto a sí a Ruiz con tanta insistencia y súplicas inoportunas: un hombre inconstante que lo apoyaba con ardor en una ocasión y ante la gente de modo que de ese hecho puedes conocer cuánto se puede confiar en la voluntad de los hombres) el gobernador ${ }^{70}$, digo, aunque habían recorrido un viaje de muchos días, ordenó que todas las pertenencias que los jesuitas llevaban consigo sean registradas. Los vehículos se detienen: ellos descienden y se retiran hacia un rancho de techo de paja. Los oficiales enviados, luego de depositados los pequeños arcones en la tierra, extienden las sotanas, las camisas, las medias, y las desparraman de cualquier modo, por si algún documento escrito a mano estaba oculto (pues preferentemente eso se buscaba). Los jesuitas nuevamente se retiran a sus transportes luego de que todas las pertenencias han sido exhibidas a la vista de todos a los numerosos observadores y son encerrados. Los inspectores regresan junto al gobernador que estaba en una ciudad cercana. Ellos no le aportaron pruebas; una vez más, da instrucciones el gobernador para que, durante la noche, una vez que los hermanos se dispusieron a dormir, se apoderaron de la vestimenta que usaron durante el día, se apropiaron de los objetos incautados y examinaron todos los rincones. He aquí cómo el buen gobernador se sometió al mandato real, con el cual se ordenaba que los jesuitas expulsos sean tratados con educación y bondad ${ }^{71}$. Pero, como aquel accionar ya era bastante impío, por este motivo se tomó medidas para que

\footnotetext{
${ }^{69}$ San Juan, XXI: 18.

${ }^{70}$ Juan Manuel Fernández Campero (Abionzo, 1725 - Madrid, 1791) fue un militar español y funcionario de la Corona Española que en el año 1764 fue nombrado gobernador de Tucumán. Realizó expediciones al interior del Chaco en ese mismo año que no tuvieron el resultado que se esperaba en virtud de que los aborígenes, mejor conocedores del terreno, con mayor movilidad y mayor resistencia a la fatiga y a las privaciones, se ocultaban rápidamente al paso de las tropas o se confederaban para presentar batalla cuando la ocasión y el lugar se presentaban propicios. Campero nombró como teniente de gobernador de Santiago del Estero al Gral. Manuel del Castaño, quien fue el encargado de cumplir la orden de Carlos III de expulsar a los jesuitas del territorio del Virreinato (Cfr. nota $\mathrm{n}^{\mathrm{o}} 16$ ).

${ }^{71}$ En el Real Decreto de Expulsión dictado por Carlos III dado en el Prado el 2 de abril de 1767 no se dan instrucciones precisas de buen trato a los jesuitas pero sólo se puntualiza: "Prohíbo expresamente que nadie pueda escribir, declamar o conmover con pretexto de estas providencias en pro ni en contra de ellas; antes impongo silencio en esta materia a todos mis vasallos y mando que a los contraventores se les castigue como reos de Lesa Majestad".
} 
por voluntad del Obispo (que había muerto hace tiempo) un religioso estuviera presente personalmente mientras se llevaba a cabo esta inspección. Lo dicho, hecho. Llegan de improviso: un oficial registra la indumentaria de los que estaban enfermos.

XXXIX. ¿Por qué, sin embargo, se investigó con tanto empeño? A excepción de unos libros sagrados, que debían ser entregados también por orden del mismo rey, algunos de escaso valor que los españoles había dado generosamente para el uso privado de la Compañía también fueron incautados. Sin embargo, (pues se debe decir lo que es la verdad) creo que estos libros, o los de escaso valor, los regresaron al gobernador porque los oficiales, gracias a su labor diurna y nocturna, retuvieron quizá para sí mismos los objetos encontrados aunque actuaron con mucha probidad, según mi juicio, pero si se dejaban algo para ellos, se lo quedaban. También el rey católico no impidió que una suma de dinero sea suministrada a los jesuitas para su uso particular en el viaje: más aún, dispuso en documentos secretos a los magistrados que estaban por detenerlos que los prefectos de los colegios les suministrara una cierta suma de dinero (y suficientemente grande) con la que los mismos prefectos atendieran de acuerdo con su parecer las necesidades y conveniencias de las suyos (excepto los gastos del viaje y del alimento que eran sostenidos públicamente) $)^{72}$.

XL. En cuanto a lo demás, las acciones que fueron llevadas a cabo por el gobernador de ningún modo escrupuloso, no pudieron no ser molestas y desagradables tanto para Ruiz como para los compañeros de viaje. Aquel por las dificultades del camino y la tristeza de su alma, adquirió una enfermedad que creyó mortal, se preparó para el final de su vida con la confesión de toda su vida anterior con tantas lágrimas y sollozos que podían oírse inclusive fuera del dormitorio en donde yacía. Sin embargo, la fuerza del mal disminuyó y dispuestas las cosas para la navegación aún con su cuerpo débil se embarcó en la nave «Esmeralda» el 6 de mayo de $1768^{73}$.

\section{Su muerte}

XLI. En la travesía por el mar al principio comenzó a sentirse mejor pero luego, por las incomodidades de una larga navegación (que son muchas), recrudeció la enfermedad, y de nuevo le pareció morir. De este manera Dios atormentaba y purificaba a

\footnotetext{
${ }^{72}$ La expulsión de los jesuitas implicó que sus bienes fueran puestos bajo la custodia y la administración de la Corona, en la llamada "Junta de Temporalidades", medida que adoptada por Campero motivó fuertes denuncias en Tucumán y en Salta. Los partidarios de los jesuitas adujeron que parte de los bienes del Colegio de Salta habían sido traspasados al patrimonio personal de Fernández Campero, aumentando de este modo las acusaciones ante la Audiencia de Charcas, que poseía la potestad para juzgar y detener al gobernador.
}

El Virrey del Perú, ordenó a la Audiencia de Charcas la reposición del gobernador en su cargo, provocando un inesperado cambio de opinión de los vecinos de Córdoba, San Miguel de Tucumán, Salta y Jujuy a favor del gobernador. Con relación a la expulsión de los Jesuitas, el Consejo de Indias reconoció la torpeza de Fernández Campero frente a la oposición de los partidarios de estos, sin embargo declaró que su actuación había sido conforme a lo dictado por la Corona y que su administración de los bienes incautados había sido honesta, desmontando de éste modo, los rumores arrojados sobre su honor y su honra. Juan Manuel Fernández Campero fue absuelto y honrado con el hábito de la Orden de Santiago.

${ }^{73}$ La Esmeralda viajaba en solitario con 153 jesuitas de varias zonas y, según otros registros, zarpó de Buenos Aires el 17 de mayo de 1768 y llegó a El Puerto de Santa María el 21 de agosto de 1768 (Herrero Gil, 2013: 7). Entre los compañeros de viaje de Francisco Ruiz de Villegas se encontraban destacados misioneros como Florián Paucke, Martín Dobrizhoffer, José Gil, Francisco Miranda, Tomás Borrego, José Sánchez Labrador, Roque Gorostiza y Luis Olcina, entre otros. 
Ruiz y Ruiz se sometía santamente al Dios que atormenta y purifica; y nunca la actitud del que da vida, que se le manifestaba con tantos pesares, le causó disgusto; aún más, puesto que al mismo tiempo había ofrecido el sacrificio de sí mismo, de sus acciones y no sólo de su honor sino también de su gloria, siempre persistió en renovar los votos religiosos obtenidos.

XLII. Añado aquí una circunstancia menor que, sin embargo, aunque no aporta demasiado, pone suficientemente en evidencia su personalidad. Mientras estaba en el noviciado, el maestro de novicios le designó un compañero para el recitado del Santo Oficio. Este repetía las oraciones vespertinas en una hora muy incómoda para Ruiz. Sucedió que el rector del colegio preocupándose por él, le preguntó si se sentía bien. "Me siento bien" - respondió. "Pero para mi salud aquella hora dispuesta por el maestro para el sagrado oficio es poco apta" (por el calor, estimo, que durante el verano es muy grande en Córdoba hasta que el fuerte sol se dirige hacia su ocaso). Entonces el Rector dijo: «le llamaré la atención al maestro por este hecho". Ruiz, por el contrario, dijo: «si me aprecias, te suplico que no hagas eso; en efecto, esta incomodidad al entonar los salmos servirá como expiación de mis faltas de otros tiempos".

XLIII. En lo que se refiere a los momentos finales, había una expresión de Ruiz durante los viajes por tierra y los quebrantos del mar que hemos aprendido de uno de sus compañeros. El Señor da, el Señor quita; bendito sea el nombre del Señor ${ }^{74}$ : sin embargo, postrado por la enfermedad a menudo decía en sus últimos momentos: cúmplase la voluntad de mi Dios en $m i^{75}$. Al mismo tiempo, mientras yacía entre tantos males, también estaba oprimido por las preocupaciones por los sucesos presentes sin recibir ningún alivio por parte de los hombres; pronunció algunas palabras junto a un amigo íntimo suyo, con las que dio a conocer que ese hecho le significaba un dolor: pero luego sufriendo por ese dolor manifiesto, ordenó que aquel familiar suyo sea llamado junto a sí y le pidió un favor porque el dolor de su alma poco resiste podría transformarse en una vergüenza para él.

XLIV. Pronto se acerca el fin. En el Puerto de Santa María próximo a la muerte confesó nuevamente las faltas de toda su vida y provisto del divino alimento y de la sagrada unción regresó su alma a Dios el 12 de septiembre de 1768, en la fiesta religiosa de la Virgen del Milagro, cuyo día festivo siempre había celebrado piadosamente y procuraba que también fuera celebrado por otros: como si quisiera la Virgen madre de Dios tener consigo a su devoto especialmente en ese día. Tenía 68 años, de los cuales alrededor de 10 vivió en la Compañía de Jesús.

\section{Bibliografía}

Benito, José Antonio (1996). "Historia de la Bula de la Cruzada en Indias". Revista de Estudios históricos-jurídicos, Sección Historia del Derecho, XVIII, Valparaíso, Chile.

Baptista, J. (2001a). "Bandiera, Domingo (Domenico). Misionero, escritor”. En O'Neill SI, Charles y Domínguez SI, Joaquín $\mathrm{M}^{\mathrm{a}}$ (directores). Diccionario histórico de la Compañía de Jesús. Biográfico-Temático Tomo I. Roma / Madrid: Institutum Historicum SI / Universidad Pontificia de Comillas.

\footnotetext{
${ }^{74}$ Job, 1: 21.

${ }^{75}$ Mateo, 6: 10.
} 
Baptista J (2001b). “Castañares, Agustín de. Misionero, víctima de la violencia”. En O'Neill SI, Charles y Domínguez SI, Joaquín $\mathrm{M}^{\mathrm{a}}$ (directores). Diccionario histórico de la Compañía de Jesús. Biográfico-Temático Tomo I. Roma / Madrid: Institutum Historicum SI / Universidad Pontificia de Comillas.

Baptista, J. (2001c). "Angulo, Francisco de. Misionero, primer superior en la Argentina". En O'Neill SI, Charles y Domínguez SI, Joaquín $\mathrm{M}^{\mathrm{a}}$ (directores). Diccionario histórico de la Compañía de Jesús. Biográfico-Temático Tomo I. Roma / Madrid: Institutum Historicum SI / Universidad Pontificia de Comillas.

Bruno, Cayetano (1975). Historia de la Iglesia en la Argentina, Tomo I, Buenos Aires: Ed. Don Bosco.

Cartas Anuas de la Provincia Jesuítica del Paraguay 1689/1700 (2015). Introducción María Laura Salinas y Julio Folkenand. Asunción: Centro de Estudios Antropológicos de la Universidad católica.

Casasola, Verónica (2014). "Vicente Capuano, el último jesuita". El Tribuno. Salta. 25 de mayo. http://www.eltribuno.info/vicente-capuano-el-ultimo-jesuita-saltan407432.

Chiaramonte, José Carlos (2007). Ciudades, provincias, Estados: orígenes de la Nación Argentina (1800-1846), Biblioteca del Pensamiento Argentino I, Buenos Aires: Ed. Emecé.

Furlong, Guillermo (1939). Entre los Vilelas de Salta, Buenos Aires: Academia Literaria del Plata.

(1984). Los jesuitas y la cultura rioplatense. Buenos Aires: Ed. Universidad del Salvador.

Gallardo, Cristian Arnaldo (2016). El milagro de la misericordia: reflexiones en torno a las fiestas en honor al Señor y a la Virgen del Milagro. Salta: Ed. Eucasa, Universidad Católica de Salta.

Herrero Gil, María Dolores (2013). "De las misiones guaraníticas al comercio de Cádiz: Francisco del Llano San Ginés o la acumulación originaria del capital". $\mathrm{Na}$ veg@mérica. Revista electrónica editada por la Asociación Española de Americanistas de la Universidad de Murcia, n.10.

Lozano SJ, Pedro (1755). Historia de la Compañía de Jesús de la Provincia del Paraguay, Tomo II, Madrid: Imprenta de la viuda de Manuel Fernández.

Marín Barriguete, Fermín (2003). "Los jesuitas y el culto mariano: la congregación de la Natividad en la casa profesa de Madrid", en Tiempos Modernos $\mathrm{N}^{\circ} 9$.

Martínez Tornero, Carlos A. (2014). “Aproximación a la identidad de los jesuitas hispanos expulsos" en El nacimiento de la libertad en la península ibérica y Latinoamérica. Actas del XVI Congreso Internacional de Ahila, San Fernando (España).

Miranda, Francisco Javier (2013). El Fiscal Fiscalizado, Estudio introductorio, transcripción y notas de Enrique Giménez López. Alicante: Publicaciones de la Universidad de Alicante. 
O'Neill SI, C. y Viscardi C. S. (2001). “Clemente XIII Carlos Renzzonico”. En O'Neill SI, Charles y Domínguez SI, Joaquín $\mathrm{M}^{\mathrm{a}}$ (directores). Diccionario histórico de la Compañía de Jesús. Biográfico-Temático Tomo I. Roma / Madrid: Institutum Historicum SI / Universidad Pontificia de Comillas.

Orosz, Ladislao, S. J. (2002) [1734]. Tratado sobre la Bula de Cruzada, Edición de Estela M. Astrada y Julieta M. Consigli. Córdoba: Ed. El Copista.

Page, Carlos A. (2011a). "La cubierta y pinturas de la iglesia de la Compañía de Jesús en la ciudad de Córdoba (Argentina)", Artigrama, núm. 26, 2011, pp. 625-648.

(2011b). "Hacia el milagro de la Inmaculada en Santa Fe. Vida y martirio del P. Pedro de Espinosa y un aporte a la arquitectura jesuítico-guaraní”. Revista oficial de la Junta de Estudios Históricos Santa Fe, No LXIX, Santa Fe de la Veracruz.

(2011c). Relatos del exilio. Memorias de los jesuitas expulsados de la antigua provincia del Paraguay. Asunción: Servilibro.

(2012) La vida del novicio jesuita José Clemente Baigorrí escrita por el P. Gaspar Juárez. Córdoba: Báez Ediciones.

Peña de Bascary, Sara (2006). “Las ruinas jesuíticas de San Miguel de Tucumán”. Revista Junta Estudios Históricos № 12, Tucumán.

Peramás, José Manuel (1791). De vita et moribus sex sacerdotum Paraguaycorum, Faventiae, Ex Typographia Archii. Fue traducido por Antonio Ballus (1946). Vida y obra de seis humanistas. Buenos Aires: Ed. Huarpes.

- (1793) De vita et moribus tredecim virorum Paraguaycorum., Faventiae: Ex Typographia Archii.

(2011). Laudationes quinque, edición bilingüe anotada por Marcela A. Suárez. Buenos Aires: Biblioteca Nacional de la República Argentina.

Sánchez, Luis; Kalinowski, Juan y Demaría, Fabiana (2012). Retórica latina rioplatense: las prolusiones jesuíticas. Córdoba: Ediciones del Copista.

Storni, Hugo (1980). Catálogo de los jesuitas de la Provincia del Paraguay (Cuenca del Plata) 1585 -1768. Roma: Institutum Historicum SI.

Toscano, José (1907). El primitivo obispado del Tucumán. La Iglesia de Salta. Tomo I, Estudios Históricos. Buenos Aires: Imprenta de M. Biedma.

Vergara, Javier (2005). "Datos y fuentes para el estudio de los seminarios conciliares en Hispanoamérica: 1563-1800”. Archivos de Historia de la Iglesia 14, pp. 239300. 